Portland State University

PDXScholar

11-13-1995

\title{
Social Support as a Buffer of the Relationship between Work and Family Involvement and Work- Family Conflict
}

Tracy Lynn Monzon

Portland State University

Follow this and additional works at: https://pdxscholar.library.pdx.edu/open_access_etds

Part of the Psychology Commons

Let us know how access to this document benefits you.

Recommended Citation

Monzon, Tracy Lynn, "Social Support as a Buffer of the Relationship between Work and Family Involvement and Work-Family Conflict" (1995). Dissertations and Theses. Paper 5156.

https://doi.org/10.15760/etd.7032

This Thesis is brought to you for free and open access. It has been accepted for inclusion in Dissertations and Theses by an authorized administrator of PDXScholar. Please contact us if we can make this document more accessible: pdxscholar@pdx.edu. 
The abstract and thesis of Tracy Lynn Monzon for the Master of Science in Psychology were presented November 13, 1995, and accepted by the thesis committee and the department.

COMMITTEE APPROVALS:

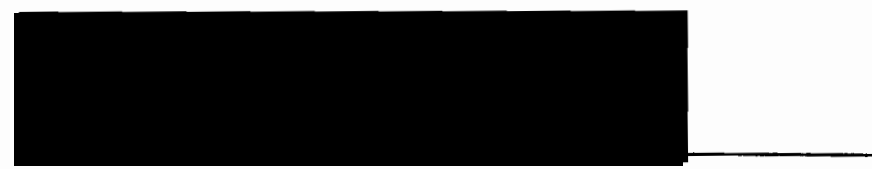

Leslie Hammer, Chair

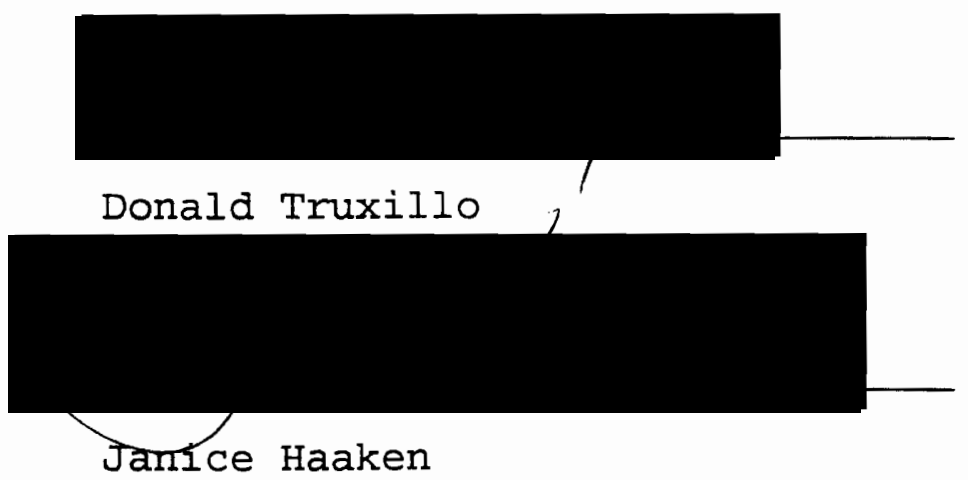

DEPARTMENT APPROVAL:

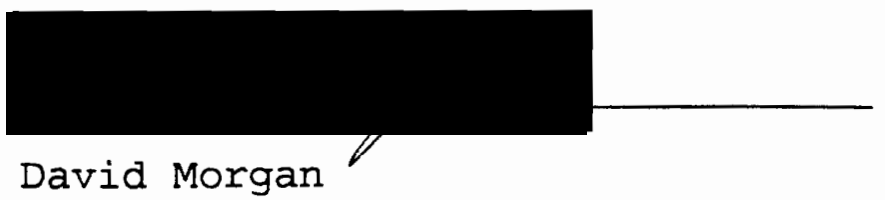

Representative of the Office of Graduate Studies

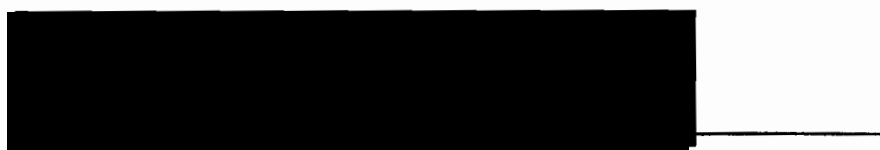

James Paulson, Chair

Department of Psychology

ACCEPTED FOR PORTLAND STATE UNIVERSITY BY THE LIBRARY by

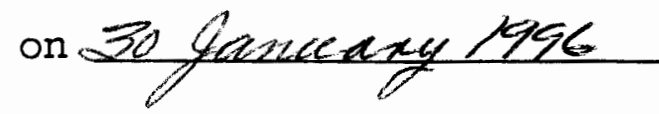


An abstract of the thesis of Tracy Lynn Monzon for the Master of Science in Psychology presented November 13, 1995.

Title: Social Support as a Buffer of the Relationship Between Work and Family Involvement and Work-Family Conflict.

With dual-career couples and single-parent families on the rise, adults may find themselves overloaded with work and family responsibilities, resulting in the experience of work-family conflict (WFC). Further, employers appear to be demanding more from their employees, while giving less. Therefore, it is important to discover ways in which to manage the conflict between the work and family domains.

Since level of involvement within a particular domain has been previously demonstrated to have a positive effect on WFC, the present study examined the possible moderating effects of social support on the relationship between work and family involvement and WFC.

Surveys assessing work and family issues and dependent care needs were distributed to a random sample of university faculty, staff, and students. Since WFC was a focus of the present study, surveys from those respondents who met the following criteria were analyzed: a) those who worked more than 20 hours per week, and b) those who had either a partner or a child, resulting in a sample size of 203 . 
Based upon factor analyses results, social support and WFC were addressed in terms of their subscales. Specifically, social support was assessed from three sources: a) partner; b) supervisor/co-workers; and c) friends/relatives. WFC was assessed as work interference with family (WIF) and family interference with work (FIW). Multiple hierarchical regression analyses indicated that family involvement was a significant predictor of both WIF and FIW, however, work involvement did not appear to have a positive effect on either type of WFC. Buffering effects of social support from all three sources were demonstrated for the relationship between family involvement and FIW. Additionally, social support from partner and from supervisor/co-workers moderated the relationship between work involvement and FIW. Further, social support from supervisor/co-workers moderated the relationship between family involvement and WIF. Finally, gender did not appear to have a significant effect on the buffering effects of social support. Limitations of the present study and future research implications are discussed. 
SOCIAL SUPPORT AS A BUFFER OF THE RELATIONSHIP BETWEEN WORK AND FAMILY INVOLVEMENT AND WORK-FAMILY CONFLICT

by

TRACY LYNN MONZON

A thesis submitted in partial fulfillment of the requirements for the degree of

MASTER OF SCIENCE

in

PSYCHOLOGY

Portland state University

1996 
Social Support as a Buffer of the Relationship Between Work and Family Involvement and Work-Family Conflict

In recent decades there has been a growing amount of research examining the consequences of social modernization, such as the rapid change in the number of roles adults play, the responsibilities associated with these roles, and the manner in which they are balanced. With the number of dualcareer couples on the rise, there is an increasing number of issues that families have to face, such as childcare (e.g., quality, cost, and availability), division of household duties (e.g., paying bills, yardwork, cooking, and housecleaning), transporting children to and from activities, and simply handling the stress of fulfilling many roles with limited time, energy, and resources.

One explanation for the lack of time that Americans have is the fact that the hours we spend at work have risen steadily over the past twenty years. This rise in work hours has been imposed by employers who continuously require more productivity from their workforce in order to keep up with or surpass the competition. In the 1930's the eighthour day and the forty-hour work week became standard, and it has remained so in spite of subsequent technological progress (Zaretsky, 1976). According to estimates by Juliet Schor (1991), average productivity of the U.S. worker has more than doubled over the past fifty years, but we have 
failed to reduce our work hours. This is in contrast to our industrial counterparts such as Germany and France, who work approximately 320 hours (around two months) less than we do each year. Accordingly, leisure time has been on the increase for various European countries, while these countries still remain industrial competitors.

According to schor (1991), there is a fallacy that capitalism has reduce human toil. In fact, the rise of capitalism has promoted a standard of living in the U.S. that can compare to no other country. There is a price to pay for fine material goods, however, and that price is precious time. If we examine those countries who are blessed with a good amount of leisure time, we might find that possibly they are not as concerned with material wealth, and are more concerned with those things that do not require money, such as quality time with their families. That is not to say that workers in the U.S. are not concerned with quality time spent with their families. This continual increase in work hours began not by choice, but with employer requirements. Nevertheless, many U.S. workers are now in a state of overload when it comes to carrying out their various responsibilities.

\section{Work and Nonwork: A Theoretical Perspective}

Work is a salient part of most people's lives, regardless of how they may feel about it. Since most people have to work to survive, it is of interest to determine 
exactly what effects work has on other areas of life, or the relationship between work and nonwork.

Friedrich Engels began to inspect the working lives of the English in the mid 19th century. Engels (1894) examined the poor conditions of the working class in England, and the effects of these conditions on their physical and emotional health. Engels described the consequences of overwork on women and children, including blindness and even body deformity. An often-cited passage displays the mental state of the male workers:
Man knows no greater happiness than that which is derived from productive work voluntarily undertaken. On the other hand, man knows no more degrading or unbearable misery than forced labour. No worse fate can befall a man than to have to work every day from morning to night against his will at a job that he abhors. (p. 133).

It was apparent to Engels that workers during this time were for the most part deprived of pleasure, with the exceptions of liquor and sexual indulgence, which the workers seemed to take part in to excess. Herein lies the beginnings of theory regarding the nature of work and nonwork. Engels states, 
The worker comes home tired and exhausted from his labours. He finds that his comfortless and unattractive dwelling is both damp and dirty. He urgently needs some stimulant; he must have something to recompense him for his labours during the day and enable him to face the prospect of the next day's dreary toil. (p. 116).

Engels' analysis is an early version of contemporary compensatory theory. This theory assumes that the needs which are not satisfactorily met through an individual's work will be sought out and satisfied through activities outside of work. In other words, certain outside interests and activities are specifically chosen in order to provide some form of fulfillment because the individual has not been fulfilled at work.

Wilensky (1960) recognized another theory within the writings of Engels, the spillover theory. This theory assumes that the routine of work will be carried over into nonwork activities, or that there will be a similarity between what takes place in one domain and what takes place in the other. For example, the textile mill workers that Engels wrote about had miserable jobs consisting of repetitive, uninteresting tasks. While some workers compensated by overindulging in sexual relations and liquor whenever possible, others continued the uninteresting 
monotony outside of work. In other words, they took interest and participated in nothing because this was the pattern at work, a pattern that carried over into private life. This is the nature of the spillover theory. In other words, activities outside of work are specifically chosen because they are similar to the activities performed at work.

Although the present discussion has referred to the interests and activities outside of work as 'nonwork', the discussion now turns to a specific domain within nonwork, that of the family domain.

Work and family. There was a time when work and family were basically the same, or served the same function. For example, Zaretsky (1976) states, "In pre-capitalist society the family performed such present functions as reproduction, care of the sick and aged, shelter, the maintenance of personal property, and regulation of sexuality, as well as the basic forms of material production necessary to sustain life" (p. 26). Capitalism forced a separation between production as wage labor and production taking place within the family, leading to the creation of a nonfamial social sphere for the male wage earner. The home also became a refuge for the men after a stressful day at work. While women continued their work within the home as housewives and mothers, their work became devalued since it did not contribute to the production of commodities. Thus, work and 
family were not separated for women, but were one and the same. According to zaretsky, by the end of the 19th century the responsibilities of the housewife grew to include the preservation of human values. Housewives and mothers were responsible for raising children with good morals, and also with all aspects of personal relations. Thus, with the sexual division of labor, women were identified with emotional life, while men were identified with the struggle for existence (Zaretsky, 1976). Therefore, with the entrance of women into the workforce, many feared the destruction of the family, as well as the loss of personal services and economic control over women.

Sokoloff (1980) notes that women's employment is often described as being disruptive to the family, suggesting an assumption that women's place and primary responsibility is and should be as wife, mother, and homemaker. Women's work in the home became even further devalued with the expansion of education, old-age homes, social services, and hospitals. The family then acquired new functions, such as an arena to seek out and find personal happiness, love, and fulfillment.

Let us return now to the various theories that have been formulated to hypothesize about the nature of the relationship between work and nonwork, and specifically between the work and family domains. Zedeck and Mosier (1990) reviewed various theories regarding the possible relationships between work and family domains. The most 
prevalent of the proposed theories included the spillover and compensatory theories previously discussed.

In addition, another line of thinking emerged in support of segmentation theory. This theory assumes that what goes on in one domain has no effect on what goes on in the other domain. Therefore, it could be that activities within both domains may or may not be similar. The key element with this theory is that activities chosen within the family domain, for example, are not chosen because of what takes place within the work domain. Those who prescribe to this theory suggest that individuals have the ability to compartmentalize and make decisions regarding certain aspects of their lives without the influence of other aspects of their lives. Most research examining the relationship between work and family domains supports the spillover theory (Zedeck \& Mosier, 1990). For example, Evans and Bartolome (1984) conducted interviews with 44 male managers and their wives to determine the types of relationships that exist between these two domains. Results indicated that most of those interviewed described patterns consistent with the spillover model. However, the severity of the spillover (how much influence the work domain had on the family domain) differed with respect to where the manager was in his career. For example, younger managers tended to have more spillover into their families than the older managers. This could be due to the fact that younger 
managers may be more concerned with issues such as job security, and therefore tend to place greater importance on their work roles at that particular time in their lives, resulting in a stronger tendency to allow work issues to have an influence on family issues. Older managers, however, may have shifted their focus to their family roles, or may have learned ways in which to block the impact of their work lives on their family lives.

In other research, Gutek, Searle, and Klepa (1991) present two additional frameworks for understanding the nature of work-family conflict (WFC), by examining the possible relationships between the work and family domains. These authors specifically examined WFC consisting of work interfering with family (WIF) and family interfering with work (FIW). Completed questionnaires from 534 male and female psychologists from two divisions of the American Psychological Association (APA) were analyzed. Criteria for inclusion consisted of those individuals who lived with a spouse, significant other, or children. The first explanation of the nature of WFC, the rational view, posits that the amount of conflict an individual perceives is in direct proportion to the number of hours expended within a particular domain. For example, those who spend larger amounts of time within the work and family domains will naturally experience more WFC than those individuals who spend less time within the work and family domains. In 
contrast, the gender role perspective suggests that gender role explanations may moderate the relationship between hours invested in a particular domain and perceived WFC. In other words, gender role expectations may alter the rational view in that men and women may perceive WFC in a manner that is consistent with gender role expectations, such that additional hours of work expended in one's own gender role domain (e.g., more hours of housework for women and more hours of paid work for men) would seem like less of an imposition for the individual than additional hours expended within the domain of the opposite gender.

Gutek et al. (1991) found support for both theories. Specifically, results indicated that men and women reported more WIF than FIW, consistent with the rational view in that both men and women reported spending larger amounts of time in paid work than in family work. However, Gutek et al. also found that when men and women invested the same number of hours in paid work, women reported more WIF than men. Accordingly, when men and women invested the same number of hours in family work, men reported more FIW than women. Overall, the high correlation between the number of hours expended in a domain and the conflict originating in that domain lends support to the rational view. Nevertheless, results also suggested that men and women interpret their invested time and their perceptions of conflict in a manner consistent with gender role expectations. Therefore, it is 
still unclear as to the exact nature of these complex relationships.

As mentioned earlier, the production work of the family has been devalued. However, children need to be taken care of, property needs to be maintained, and meals need to be cooked, etc. With individuals now facing such a wide array of responsibilities, it is not surprising that many of them experience role conflict when trying to carry out these responsibilities. Individuals may experience role conflict when they are highly involved in one or more roles, when they perceive that there is not enough time to perform their roles adequately, or when they are trying to live up to their own (or someone else's) unrealistic expectations. With work time on the increase, numerous individuals experience conflict between their work roles and their family roles, or work-family conflict (WFC). Work-Family Conflict

According to Kahn, Wolfe, Quinn, Snoek, and Rosenthal (1964), role conflict is a result of incompatible pressures within a certain role or domain. For example, work conflict occurs when an individual is faced with incompatible pressures within the work domain, while family conflict occurs when an individual is faced with incompatible pressures within the family domain. Consequently, WFC results as a form of interrole conflict where fulfilling one of the roles becomes incompatible with fulfilling the other 
role (Greenhaus \& Beutell, 1985; Kahn, et al., 1964).

In their review of the sources of WFC, Greenhaus and Beutell (1985) describe three types of interrole conflict: 1) Time-based conflict; 2) Strain-based conflict; and 3) Behavior-based conflict. Time-based conflict occurs when time devoted to one role makes it difficult to fulfill requirements of another role. Possible types of time-based conflict include excessive work time, inflexible schedules, and role overload. For example, a mother whose job requires that she work frequent overtime, while her children are in need of transportation to and from extracurricular activities may be experiencing time-based conflict. Strainbased conflict occurs when strain produced by one role makes it difficult to fulfill requirements of another role, such as stress at work, stress at home, and lack of partner support. For example, the mother from the above example has a partner who has more time in his schedule to tend to the children. However, he also participates in activities that are top priority for him, and therefore, his overworked wife is left with the responsibility for the children, resulting in her experience of strain-based conflict. Behavior-based conflict occurs when behavior required by one role makes it difficult to fulfill requirements of another role. An example of this type of conflict would be that in the workplace, admired behaviors may include aggressiveness and competitiveness, while desired behaviors at home may be 
compassion, forgiveness, and cooperation. Conflict then occurs when individuals have difficulty changing their behaviors from one role to the next. For instance, the same mother works in the collections department at a financial institution. All day long, she phones people regarding their past due accounts, and she hears excuse after excuse as to why people cannot pay their bills. When customers have accounts that are very delinquent, she must repossess property such as cars from these people, resulting in all sorts of verbal abuse. Her job requires that she be tough, and that she not get too compassionate about the plight of the customer. At home, however, she needs to display plenty of patience and compassion with her partner and children, which is sometimes difficult to do after an extremely rough day as a collections agent.

Since it appears that the hours we spend at work will not decrease anytime in the near future, it is of utmost importance to discover ways in which to alleviate the pressures of handling so many roles and responsibilities and thus to reduce WFC. High levels of WFC can lead to several negative outcomes such as role overload, increased health risks, decreased productivity at work, reduced work and family satisfaction, and poorer parental performance (Greenhaus \& Beutell, 1985; Kelly \& Voydanoff, 1985; Pleck, Staines, \& Lang, 1980).

Sources of WFC. Various sources which are believed to 
be contributors to WFC have been investigated. Greenhaus and Beutell's (1985) review indicated several factors contributing to the three types of conflict (i.e., timebased, strain-based, and behavior-based). Contributing to time-based conflict were number of hours worked, flexibility of the work schedule, shiftwork, having young children, spousal employment patterns, and having a large family. More specifically, the number of hours worked per week has been shown to be positively related to WFC, as well as the presence of young children and having a large family. Flexibility of the work schedule has been demonstrated to have an inverse relationship with WFC, such that the less flexible the schedule, the higher the WFC. Also, those whose jobs require them (or their spouse) to work shifts other than a full-time day shift (9 to 5) tend to experience more WFC. According to the review, contributors to strainbased conflict were role conflict (conflicts arising due to attempts at fulfilling too many roles), role ambiguity (not having a clear understanding of the expectations or required behaviors associated with a role), amount of boundaryspanning activities (number of activities required by one domain which interfere with the other domain when they are carried out), family conflict (such as having too many family responsibilities), and low spousal support (such as attempting to take care of the family, work outside of the home, and attend classes, without the help and encouragement 
of the partner). Finally, those variables found to be contributors to behavior-based conflict were expectations for secretiveness and objectivity at work (resulting from competition, for instance), and expectations for warmth and openness at home (including patience and forgiveness).

Burke (1988) surveyed 828 men and women employed in police work, who were attending various educational offerings related to their jobs. The purpose of the study was to test a model which proposes that work setting characteristics lead to work stressors (and family characteristics lead to family stressors), which in turn lead to WFC, resulting in various outcome variables (e.g., job satisfaction, psychological burnout, emotional detachment). Results indicated positive relationships between both work and family stressors and WFC. These work and family stressors included negative work setting (e.g., lack of autonomy, social isolation, heavy workload, lack of stimulation), shiftwork (i.e., working varying shifts including evening and graveyard shifts), and the experience of negative life events (e.g., divorce, death of a close friend or relative) during the previous year. In other research, Pleck, et al. (1980) examined data gathered from the Quality of Employment Survey of 1977 which was conducted for the U.S. Department of Labor by the University of Michigan. Specifically, the authors examined data gathered from married workers with a child under the age of 18 . 
Results indicated that excessive work time, schedule conflicts, and irritability and fatigue were common causes of interference betweeen work and family roles. In addition, working a large number of hours, high frequency of overtime, working a schedule other than nine to five, and demanding work (physically or emotionally) were all significant contributors to WFC.

Greenhaus, Parasuraman, Granrose, Rabinowitz, and Beutell (1989) surveyed 119 dual-career couples in order to clarify work-related antecedents of WFC. Specifically, work role stressors, task characteristics, work salience (for self and partner), work schedule characteristics, and WFC were all measured. Results indicated that work role stressors (role conflict, role ambiguity, and role overload) accounted for a significant amount of variance in both timeand strain-based conflict, with role overload being the most persistent predictor of the two types of WFC. Parasuraman, Greenhaus and Granrose (1992) examined family stressors such as family conflict and parenthood among the same 119 two-career couples, and found that these variables were also positively related to WFC.

Pleck (1977) suggested that the boundaries between work and family domains were asymmetrically permeable for men and women. For example, it is more acceptable (and usually expected) for women to allow family matters to interfere with their work, such that if there is a sick child to 
attend to, the working mother is typically the one called upon to take responsibility. Likewise, it is more acceptable for men to allow their work stress to interfere with their families, such that there are fewer expectations for working fathers to actually set work aside when they come home. In other words, there appears to be a gender difference in the direction of the spillover between work and family domains, such that women tend to have spillover from the family domain into the work domain, while men tend to have spillover from the work domain into the family domain. Still others, however, found no gender differences with respect to how the work and family domains affect each other (Bedeian, Burke, \& Moffett, 1988; Frone, Russell, \& Cooper, 1992), thus the effects of gender are inconclusive.

In addition to the above mentioned sources of WFC, research has indicated that the extent to which an individual is involved within a role may have an effect on the amount of conflict that is experienced by the individual. For example, several researchers have indicated a correlation between high levels of work involvement and high levels of WFC (Frone \& Rice, 1987; Higgins, Duxbury, \& Irving, 1992), and also between high levels of family involvement and WFC (Frone et al., 1992).

The effects of work and family involvement on WFC. Some researchers have suggested possible explanations for the relationship between role involvement and WFC. In their 
review Greenhaus and Beutell (1985) suggest that high levels of involvement can lead to role overload, which results when an individual's time and energy demands are too great, hindering the individual from adequately performing the role. According to Kanungo (1979), work involvement can be viewed as the extent to which individuals identify psychologically with their work, while viewing their work as having the potential to satisfy their salient needs and expectations. In a study on the patterns of work and family involvement in single- and dual-earner couples, Yogev and Brett (1985) defined family involvement as the degree to which an individual identifies with his or her family role, and how important this identification is to the individual's self-concept .

Higgins et al. (1992) conducted a survey in order to test a model of the relationships between work conflict, family conflict, WFC, quality of work life, quality of family life, and overall life satisfaction. Participants included 220 individuals who lived with a significant other. Additional criteria stipulated that both partners worked full time outside of the home in managerial or professional jobs, and had children living in the home. Results indicated that work involvement was a significant predictor of WFC. Further, WFC had a significant negative effect on quality of work life and family life, which were both highly related to overall life satisfaction. 
Duxbury and Higgins (1991) examined gender differences in the relationships between work and family involvement and WFC. Subjects consisted of 131 men and 109 women who were married with children living in the home. Additionally, both spouses worked full time outside of the home in managerial or professional jobs. Results indicated that work involvement was a stronger predictor of WFC among women than among men, and that family involvement was a stronger predictor of WFC among men than among women. Duxbury and Higgins suggest that these relationships can be explained by examining traditional versus nontraditional roles. They suggest that a traditional woman is one who is highly involved in her family role, since the family role should be more salient for women, while a nontraditional woman is one who is highly involved in her work role (which should not be the more salient role for women). Likewise, a traditional man is one who is highly involved in his work role, since the work role should be more salient for men, while a nontraditional man is one who is highly involved in his family role (which should not be the more salient role for men). Hence, those individuals who are highly involved in nontraditional roles will experience more WFC as a result of pressures evolving around traditional societal norms.

Furthermore, research by Frone et al. (1992) tested a comprehensive model of the antecedents and outcomes of two types of WFC (family-to-work and work-to-family). Using a 
sample of 631 interview subjects, the researchers demonstrated a positive relationship between family involvement and family-to-work conflict. However, the relationship between work involvement and work-to-family conflict was moderated by job type such that there was a positive relationship among white collar workers and no relationship among blue collar workers. Thus, the nature of this relationship is unclear across research studies.

It is evident that there are numerous sources which can lead to WFC. It would be beneficial then to determine ways in which to help alleviate WFC. Goff, Mount, and Jamison (1990) found that the most significant predictor of WFC was supportive supervision, such that the higher the level of supervisor support, the lower the level of WFC experienced by the employee (Goff et al., 1990). Therefore, it seems reasonable that the more support an individual receives, whether it be within the work domain (i.e., co-workers, supervisor) or within the family domain (i.e., family, friends), the less conflict is experienced by that person. In other words, social support may help to reduce WFC. Social Support

According to Lin, Simeone, Ensel, and Kuo (1979), social support can be defined as "...support accessible to an individual through social ties to other individuals, groups, and the larger community". Caplan (1974) describes two types of support, enduring and short-term. Enduring 
support is that which assists an individual with long-term or continuing burdens. Short-term support, on the other hand, is that which assists an individual with a particular problem or crisis event from time to time. Additionally, Caplan presents three key elements to these types of support:

...Both enduring and short-term supports are likely to consist of three elements: the significant others help the individual mobilize his psychological resources and master his emotional burdens; they share his tasks; and they provide him with extra supplies of money, materials, tools, skills, and cognitive guidance to improve his handling of his situation (p. 6).

House and Kahn (1985) suggest that the domain of social support is very complex, consisting of social relationships (e.g., existence, quantity), social networks (e.g., size, frequency), and actual social support (e.g., type, source). Since there has been no agreement on the operational definition of social support, likewise there has also been no agreement on how to measure it. Various researchers have attempted to measure distinct types of support. Reifman, Biernat, and Lang (1991) surveyed two hundred married professional women with children in order to determine if social support could serve as a buffer between stress and 
negative health (emotional and physical). The authors were interested in measuring social support functions such as esteem support, informational support, social companionship, and tangible support. Esteem support consists of support which makes an individual feel esteemed and valued. Informational support is that which provides advice and understanding. Social companionship involves spending recreational time with an individual fulfilling the individual's need for belongingness, and tangible support is that which provides financial or material aid to an individual. In addition, Reifman et al. obtained support indices from various sources (i.e., friends at work, friends outside of work, relatives, husband). However, the authors only asked two core questions of each of the sources, and therefore, they did not actually measure the types of support described above.

Vaux and Athanassopulou (1987) examined another area within the domain of social support, support appraisals and social networks. One hundred thirty-eight individuals were interviewed regarding the size and composition of their social networks, and the extent to which various individuals within these networks provided five different types of support. The types of support that were measured included emotional, practical, financial, advice/guidance, and socializing. However, definitions or examples of these were not provided. Results indicated that perceptions of (and 
satisfaction with) social support were associated with the size of the networks, the reciprocity and complexity of the relationships with network members, and the proportion of close friends and relatives within the network.

Social support can be provided in a number of ways and by a number of sources. For example, an individual may receive support from a partner when feeling overloaded, support from a supervisor or co-worker when dealing with familial difficulties, or support from friends or relatives when feeling troubled. An individual may seek support from different sources depending on the situation and the type of support that they are in need of (advice, companionship, etc.).

In an extensive review article Cohen and Wills (1985) suggest that the effects of social support (i.e., direct or moderating) may be dependent upon which variables within the social support domain are examined. For example, moderating effects seemed to be evident when social support was measured in response to stressful events, and main effects seemed to be demonstrated when social support was measured in terms of integration within a social network.

There is also some evidence that suggests that men and women may respond differently to social support. Although traditional roles within the family are changing, women who work still tend to carry a great deal of responsibility for household duties, including childcare (Duxbury \& Higgins, 
1991), and it has also been suggested that there exists a greater salience of the family role for women than for men (Parasuraman et al., 1992). Burda and Vaux (1987) surveyed 205 male college students at a large midwestern university and found that male subjects' belief in traditional sexrole values was negatively related to a number of social support variables such as perceived support from both males and females, emotional support from males, and practical assistance from females. Burda and Vaux suggest that masculine sex roles may dictate which are acceptable sources from which men may seek support. For example, males tended to prefer obtaining emotional support from females rather than from other males. As mentioned earlier, Greenglass, Pantony, and Burke (1988) reported that social support was associated with a lesser amount of role conflict, but only for women. These authors suggested that men may reduce their amount of conflict by prioritizing roles, whereas women tend to view the conflict as consisting of a "tradeoff" between the roles.

Moderating effects of social support. Past researchers have attempted to demonstrate a buffering effect of social support on the relationship between stressors and stress. For example, Power (1988) examined stress, psychiatric symptoms, and emotional and practical social support (from various sources) of female students at two different time points. Results indicated that the effect of stress on 
psychiatric symptoms depends on the level of support the person receives. More specifically, stress-buffering effects were found for emotional support, but not practical support. Others have also reported mixed results with respect to the moderating effect of social support within various relationships (Abbey, Abramis, \& Caplan, 1985; Etzion, 1984). Etzion examined the effects of social support (in work and in life) on the relationship between work stress and life stress and burnout of managers and human service professionals. Social support consisted of emotional concern, instrumental aid (e.g., providing financial support), information, and appraisal (e.g., perceived quality of support relationships). Participants consisted of 657 Israeli managers and social service professionals who were recruited from university classes and professional conventions. It was reported that the relationship between work stress and burnout was moderated by support in work for men (e.g., supervisor, co-workers), such that when level of social support from the work domain is high the relationship between work stress and burnout is reduced. However, this same relationship was moderated by support in life (e.g., friends, family) for women, such that when social support from friends and family is high the relationship between work stress and burnout is reduced. Further, the relationship between life stress and burnout was not moderated by support in life or support in work for 
either gender.

Others have failed to demonstrate any buffering effects of social support. Reifman et al. (1991) surveyed married professional women with small children to examine whether social support could serve as a protector against the negative health effects of stress. Results yielded no moderating effects, however. Frone, Russell, and Cooper (1991) examined the effects of job stressors, family stressors, and WFC on depression and somatic symptoms. Additionally, they examined the possible moderating effects of social support, mastery, active coping style, and selffocused attention on the above relationships. Surveys were completed by 596 employed individuals drawn from a random community sample. Results indicated that job stressors, family stressors, and WFC all predicted psychological distress. However, the only moderator of the relationships between stressors and stress was self-focused attention (a tendency to focus on internal aspects such as emotions, attitudes, thoughts, etc.). Therefore, no buffering effects of social support on the relationship between work and family stressors and psychological distress were demonstrated. Others have examined social support at work as a possible buffer between working conditions and wellbeing (Loscocco \& Spitze, 1990) and between job demands and mental and physical health (Marshall \& Barnett, 1992). Again, buffering effects were not found. 
Although there have been mixed results on the moderating effects of social support, it has been suggested that moderating effects may be dependent upon the source of the support (Abbey et al., 1985). Abbey et al. surveyed 168 undergraduates at a large midwestern university in order to determine whether social support could buffer the relationship between social conflict and emotional wellbeing. Results indicated that only support from certain sources moderated this relationship. However, the sources measured were not specific (i.e., people in your personal life, some one person, or the person closest to you), and therefore, varied for each participant. This finding suggests that individuals may use different sources of support depending on the type of social conflict, the specific situation, or the types of support that certain individuals may provide.

The effects of social support on WFC. There has been some research which has examined the possible direct effects of social support on WFC. Burke (1988) examined several antecedents and consequences of WFC. Questionnaires were distributed to 828 men and women employed in police work. Participants reporting less social support from sources outside of work also reported experiencing greater WFC.

Higgins and Duxbury (1992) also looked at antecedents and consequences of WFC between two groups of men, traditional-career men and dual-career men. Traditional- 
career men were those whose wives were homemakers, and dualcareer men were those whose wives held jobs outside of the home. The dual-career men experienced greater negative spillover from work to family than the traditional-career men. It was suggested that this finding was due to a lack of social support within the work domain for the male in the dual-career role. The authors contend that this lack of social support in the workplace stems from societal expectations of traditional role norms, such that men are not expected to become as highly involved in their family roles as in their work roles. With dual-career couples, however, men are forced to increase their familial involvement .

In another study, Greenglass et al. (1988) examined gender differences in role conflict, work stress and social support among 556 men and women who had children and were employed within a Canadian school system. Survey results indicated that women experienced significantly more interrole conflict than men did. Further, social support from two sources, (boss, friends and family), were each associated with a lesser amount of role conflict, but only for women. Likewise, as previously mentioned, Goff et al. (1990) reported that supportive supervision was related to less WFC.

Other research by Parasuraman et al. (1992) examined social support as a moderator between work and family 
stressors and well-being. Work role stressors were indicated by role conflict, role ambiguity, and role overload, while family role stressors were indicated by family conflict and parenthood. WFC consisted of timeand strain-based conflict, and well-being was assessed by job satisfaction, family satisfaction, and life stress. Social support (informational, instrumental, emotional, and appraisal) was assessed for the work domain, and also for the family domain (spousal support). Although main effects were found for social support on job and family satisfaction, no moderating effects of social support for any of the relationships between stressors and well-being were demonstrated.

The Present Study

The purpose of the present study is to investigate how social support from various sources will moderate the relationship between work involvement, family involvement, and WFC. Although the importance of measuring various types of support is recognized, the present study examines only support from various sources, due to constraints with regard to the length of the measurement instrument as well as time factors.

First the main effects of work and family involvement on WFC will be examined. Research has indicated that high levels of work involvement and family involvement increase WFC (e.g., Frone \& Rice, 1987; Higgins et al., 1992). 
Therefore, consistent with this research, the following hypotheses were tested:

Hypothesis 1: High levels of work involvement will lead to high levels of WFC.

Hypothesis 2: High levels of family involvement will lead to high levels of WFC.

Furthermore, social support has been associated with lower levels of WFC (Burke, 1988; Goff et al., 1990; Higgins \& Duxbury, 1992) and has also been demonstrated to have a buffering effect between various stressors and stress (Abbey et al., 1985; Etzion, 1984; Power, 1988). The present study specifically examined social support as a means of moderating the effects of work and family involvement on WFC. Therefore, the following hypotheses were tested:

Hypothesis 3: Social support will have a buffering effect on the relationship between work involvement and WFC, such that when social support is high the relationship between work involvement and WFC will be low, and when social support is low the relationship between work involvement and WFC will be high.

Hypothesis 4: Social support will have a buffering effect on the relationship between family involvement and WFC, such that when social support is high the relationship between family involvement and WFC will be low, and when social support is low the relationship between family involvement and WFC will be high. 
As previously mentioned, Burda and Vaux (1987) reported that the beliefs of male college students with respect to traditional sex-role values was negatively related to a number of social support variables. Additionally, it was discussed that men and women may differ in who they seek out or accept support from and how they respond to support. More specifically, women are more apt to seek out and accept support than men. Therefore, it is reasonable to expect that women would benefit more, or take better advantage of social support provisions. Thus, the following hypothesis will also be tested:

Hypothesis 5: The buffering effect of social support will be greater for women than for men.

Method

\section{Participants}

Nine-hundred randomly selected individuals from a population of faculty, staff, and students at a mid-sized urban northwestern university received questionnaires for the present study. Three-hundred and fifty-one questionnaires were returned, resulting in a $39 \%$ response rate. University records and lists were used as the source for the recruitment of participants. In addition, a few randomly selected classrooms were recruited for voluntary participation. Because the present study examined WFCissues, those respondents meeting the following criteria were included in the analyses: (a) those who worked more 
than 20 hours per week and (b) those who had either a partner or a child living in the home. Two-hundred and three respondents who met the above criteria were included in the analyses.

\section{Measures}

A questionnaire containing demographic information, as well as measures of work involvement, family involvement, social support, and work-family conflict was used for the data collection. This questionnaire was part of a larger survey on the needs of the university population with respect to work and family and child care/dependent care issues (see Appendix A).

Demographic Information. Several items (\#1-6, 14-18) were included in order to gain descriptive information about the population of participants. Some of these included age, domestic status, ethnic background, and gender.

Work Involvement. Six items (\#13n-13r, 13t) measuring work involvement were taken from a questionnaire used in a study by Misra, Ghosh, and Kanungo (1990). A sample item is as follows: "An individual's life goals should be mainly work/school oriented". The word "school" was added for the present study so that the items would be relevant to the students in the current population. Subjects responded on a 5 -point scale, where $1=$ Strongly disagree, to 5 = Strongly agree. Cronbach's alpha for the work involvement measure used in the Misra et al. study was .86 . 
Family Involvement. The family involvement measure was adapted from the Misra et al. (1990) work involvement measure. The same six items (\#13i-13m, 13s) as above were used to measure family involvement, with the word "family" substituted for the word "work" (e.g., "An individual's life goals should be mainly family oriented"). Cronbach's alpha for the family involvement measure used by Misra et al. was .87 .

Social Support. A modified version of a scale used by Caplan, Cobb, French, Van Harrison, and Pinneau (1975) was used to measure social support $(\# 12 a-12 r)$. The original scale included four items measuring support from each of three sources: (a) immediate supervisor, (b) other people at work, and (c) wife, friends and relatives, resulting in a total of 12 items. The original scale was used to assess social support in reducing work stress. A sample item from the original scale is as follows: "How much does each of the following people go out of their way to make your work life easier for you?" However, the present version was modified to also assess family stress. For example, the above item was modified to ask how much each source went out of their way to make life (in general) easier. Consistent with the previous scale, three sources of social support were assessed, although they were adapted to suit the current population (partner, supervisor/co-worker, friends/relatives). Two additional items were added to the 
measure for the present study in hopes of obtaining a broader measure of the construct: (a) "To what extent can you turn to your" (source) "to help you carry out obligations when you are overloaded"?; and (b) "To what extent can you turn to your" (source) "when you are feeling overwhelmed in order to get a new perspective on the situation"? Participants responded to each item using a 5point scale, where 1 = "Don't have any such person", to $5=$ "Very Much". The two additional items for each of the three areas of support added six items, resulting in a total of 18 items for the overall scale. Subscales of support were obtained for each source resulting in three indices, social support from partner, from supervisor/co-workers, and from friends/relatives.

Work-Family Conflict. A measure used by Burley (as cited in Gutek et al., 1991) was used to measure WFC. Two types of WFC were measured, work interference with family (WIF) and family interference with work (FIW). The measure consisted of eight items, four items each measuring WIF (\#13a-13d) and FIW (13e-13h), respectively. A sample item measuring WIF is as follows: "My family/friends dislike how often I am preoccupied with my work/school when I am at home". The word "school" was also added to this scale to ensure that the items would be relevant to all members of the current population. Cronbach's alpha for the WIF measure used in the Gutek et al. study was .82. A sample 
item measuring FIW is as follows: "My superiors and peers dislike how often I am preoccupied with my personal life while I am at work/school". Cronbach's alpha for the FIW measure used in the Gutek et al. study was .81. The WFC measure was based on a measure originally developed by Kopelman, Greenhaus, and Connolly (1983). Participants responded to each item using a 5 -point scale, where $1=$ Strongly disagree, to $5=$ Strongly agree.

\section{Procedure}

Questionnaires were mailed via campus mail to randomly selected individuals, with the exception of those going out to graduate student participants, which were mailed to their homes. Also included was a coverletter (shown in Appendix A) explaining the study, and a return envelope. Participants were asked to complete and return the questionnaires within a two-week time period. They were also guaranteed anonymity, and were informed that participation was strictly voluntary.

Results

Descriptive statistics. Of the 203 participants who met the selection criteria and were included in the analyses, $89 \%(\underline{\mathrm{n}}=180)$ were White/Non-Hispanic, $65 \%$ ( $\underline{\mathrm{n}}=$ 132) were female, 96\% $(\underline{n}=196)$ had a partner ( $84 \%$ lived with their partner), and $36 \%(\underline{n}=74)$ had at least one child 18 years old or younger living with them. The mean age of participants was 41 years $(\underline{s d}=11.06)$, and a majority $(66 \%$, 
$\underline{n}=134$ ) worked between 31 and 50 hours per week.

Means, standard deviations, and correlations for the involvement scales, the WFC subscales, and the social support subscales are given in Table 1, along with reliabilities for each (shown parenthetically). In order to determine face validity of the WFC scales, item \#22 from the survey was also included in the correlation matrix. This item assessed the ease with which respondents felt that they handled work and family responsibilities simultaneously.

Insert Table 1 about here

Dimensionality of the scales. Factor analyses were conducted for the involvement, social support, and WFC scales. Factor solutions were arrived at by using the principal components analysis followed by a varimax rotation. The rotated factor loadings for the involvement scales resulted in three factors (see Table 2). Factor 1 represented family involvement and Factor 2 represented work involvement. The third factor consisted of two items regarding extreme involvement, or absorption, within the work and family domains. However, these two items also loaded (to a lesser degree) with each of their respective involvement scales. Considering this, along with the fact that these involvement measures have been used reliably in the past, it was decided to include these two items within 
the other two involvement factors. In addition, these results could simply be an artifact of the manner in which the involvement items appeared on the survey. More specifically, the first five involvement items on the survey referred to family involvement, the next five items referred to work involvement, followed by the family absorption item, then the work absorption item. The two clear factors accounted for $55.1 \frac{0}{6}$ of the total variance $\left(67.6 \frac{\circ}{6}\right.$ including the third factor).

Insert Table 2 about here

The rotated factor loadings for the social support scale resulted in three clear factors (see Table 3). Factor 1 represented social support from partner, Factor 2 represented social support from supervisor/co-workers, and Factor 3 represented social support from friends/relatives. These three factors accounted for $79.5 \%$ of the total variance.

Insert Table 3 about here

The rotated factor loadings for the WFC scale resulted in two clear factors (see Table 4). Factor 1 represented work interference with family (WIF) and Factor 2 represented family interference with work (FIW). These two factors 
accounted for $58.2 \%$ of the total variance.

Insert Table 4 about here

Tests of hypotheses. Due to the fact that factor analysis results indicated three factors for the social support measure (one for each source) and two factors for the WFC measure (one for WIF and one for FIW), the hypotheses for the present study will be examined with respect to these evident subscales. Results of the following regression analyses are found in Tables 5-10. Hierarchical multiple regression analyses were conducted to test the main and interactive effects of work involvement, family involvement, and social support on WFC. To test Hypothesis 1, which predicted that high levels of work involvement would lead to high levels of WFC, each measure of WFC (WIF and FIW) was regressed onto work involvement. Results failed to demonstrate significant effects on either WIF or FIW.

Insert Tables 5-10 about here

Multiple regression analyses were also used to test Hypothesis 2, which predicted that high levels of family involvement would lead to high levels of WFC. To test this relationship, each measure of WFC (WIF and FIW) was 
regressed onto family involvement. Results indicated that family involvement was significantly related to FIW $\beta=$ $.15, \underline{\mathrm{p}}<.05)$, and also to $\operatorname{WIF}(\beta=.14, \underline{\mathrm{p}}=.05)$, thus supporting Hypothesis 2. Hierarchical multiple regression was used to test Hypothesis 3, which predicted that social support would have a moderating effect on the relationship between work involvement and WFC. To test this hypothesis, the three interaction terms for each source of social support were regressed onto WIF and FIW, respectively. The change in $\mathrm{R}^{2}$ was tested to determine the interaction effects above and beyond the main effects for each interaction. A moderator effect was found for social support from partner on the relationship between work involvement and $F I W\left(\Delta R^{2}=\right.$ $.02, \underline{F}=10.79$; see Table 6), as well as a moderator effect for social support from supervisor/co-workers on the relationship between work involvement and FIW $\left(\Delta R^{2}=.01, \underline{F}\right.$ $=1.76 ;$ see Table 7). To examine the direction of the interactions, the sample was divided into low and high groups of social support from both partner and supervisor/co-workers according to the median. Means were obtained for both low and high groups in order to plot the effects. Figure 1 shows the plotted lines for low and high support from partner, and Figure 2 shows the plotted lines for low and high support from supervisor/co-workers. According to the figures, when work involvement was high social support reduced the relationship between work 
involvement and FIW. However, when work involvement was low, social support did not appear to have an effect on the relationship. No moderator effects were found for social support from friends/relatives on the relationship between work involvement and either FIW or WIF. Likewise, partner support and support from supervisor/co-workers demonstrated no moderating effects on the relationship between work involvement and WIF. Thus, Hypothesis 3 was partially supported.

Hypothesis 4 predicted that social support would have a moderating effect on the relationship between family involvement and WFC. Hierarchical multiple regression was used to test the change in $\mathrm{R}^{2}$ for the interaction effects after controlling for the main effects. Again, the three interaction terms for each source of social support were regressed onto WIF and FIW, respectively. Results indicated moderator effects for social support from friends/relatives $\left(\Delta R^{2}=.01, \underline{F}=9.16 ;\right.$ see Table 5$)$, social support from partner $\left(\Delta R^{2}=.01, \underline{F}=14.08\right.$; see Table 6) and social support from supervisor/co-workers $\left(\Delta R^{2}=.01, \underline{F}=4.45\right.$; see Table 7) on the relationship between family involvement and FIW. In order to examine the nature of these interactions, the sample was divided into low and high support groups according to the median for each type of support. Means were again obtained for the low and high groups of support in order to plot the effects. Plotted lines for low and 
high support from friends/relatives are shown in Figure 3, plotted lines for low and high support from partner are shown in Figure 4, and plotted lines for low and high support from supervisor/co-workers are shown in Figure 5. The figures show that the moderating effects are such that when family involvement was high, social support (from all three sources) decreased the relationship between family involvement and FIW. There appeared to be no effect, however, for social support at low levels of family involvement. Additionally, a moderator effect was found for social support from supervisor/co-workers on the relationship between family involvement and WIF $\left(\Delta R^{2}=.01\right.$, $\underline{E}=3.97$; see Table 10). Again, in order to examine the nature of the interaction, the sample was divided into low and high support according to the median. Means were obtained for the low and high groups of support in order to plot the effects. The plotted lines for low and high social support from supervisor/co-workers are shown in Figure 6 . According to the figure, when family involvement is high social support from supervisor/co-workers decreases the relationship between family involvement and WIF, and when family involvement is low social support does not seem to have an effect. No moderator effects were found, however, for social support from friends/relatives or from partner on WIF. Therefore, Hypothesis 4 was partially supported. Hypothesis 5 predicted that the moderating effect of 
social support on the relationships between work involvement and WFC, and between family involvement and WFC would be greater for women than for men. In order to test this relationship, hierarchical multiple regression analyses were conducted two additional times, once including only the women in the sample, and again including only the men in the sample (see Tables 11-12). The test of the interaction effects indicated a significant interaction of social support from supervisor/co-workers on the relationship between family involvement and WIF, but only for women. There were also moderator effects evident only for the male sample. Specifically, there were moderator effects for social support from supervisor/co-workers on the relationship between work involvement and FIW, and for social support from friends/relatives on the relationships between family involvement and FIW and between work involvement and FIW. Significant moderator effects were found in both samples for social support from partner on the relationships between both work and family involvement and FIW, and for social support from supervisor/co-workers on the relationship between family involvement and FIW. To further understand the gender effects, the differences between genders were tested. Although there were several interaction effects which were significantly different from zero, none of the relationships between the men and the women were significantly different from each other. 
Therefore, Hypothesis 5 was not supported.

Insert Tables 11-12 about here

Discussion

\section{Tests of Hypotheses}

Previous research has indicated that high levels of work involvement lead to high levels of WFC (Frone \& Rice, 1987; Higgins et al., 1992). Therefore, Hypothesis 1 was intended to replicate these findings. Surprisingly, results from the present study did not support the positive relationship between work involvement and WFC. One possible explanation for this finding is that the results are simply an artifact of the survey itself. Due to the fact that the survey participants were composed of faculty, staff, and students, the word "school" was added wherever the word "work" appeared (i.e., "work/school"), with the intention that the survey items could apply to any member of the current population. This addition was carried out throughout the work involvement items as well as the WFC items. It is possible that this wording may have caused some confusion, or that those students who also worked may have had some difficulty deciding which area to respond to, work or school. Although analyses for the present sample were conducted only for those individuals who currently worked over 20 hours per week, there may be a significant 
difference in level of work involvement between those individuals who work 25 hours per week and versus those individuals who work 40 hours per week.

In addition, a more refined measure of involvement should be used. Although the present study utilized a widely-used measure of involvement (measuring work and family), a factor analysis indicated that two items from the measure (assessing the importance of absorption in work and family, respectively) resulted in a third factor. In comparing these two items with the rest of the measure, they seem to assess involvement in the work and family domains at an extreme level.

It also may have been interesting to examine partner's level of involvement. Beutell and Greenhaus (1982) found that couples who both exhibited high work-role-salience (including high work involvement) reported, surprisingly, the same amount of interrole conflict as couples who both exhibited low work-role-salience. It was suggested that partners who are both highly involved in their work may be more accommodating with respect to each other's needs and aspirations. Similarly, Greenhaus et al. (1989) reported that men who demonstrated high work involvement, and who had partners who also demonstrated high work involvement, experienced relatively low levels of WFC. However, we do not have information on partner's level of work involvement, which makes testing this assumption impossible. 
Additionally, as previously mentioned, Frone et al. (1992) reported that the relationship between work involvement and WFC was dependent upon the individual's job type, such that work involvement had a positive relationship with WFC for white collar workers, but had no relationship among blue collar workers. Hence, the relationship between work involvement and WFC appears to be more complex and therefore, a more in-depth examination of this relationship is necessary.

The present study also attempted to replicate previous findings regarding the positive relationship between family involvement and WFC (Frone et al., 1992). Results of this study are in support of these findings, since family involvement was a significant predictor of both WIF and FIW. Although it is understandable that family involvement would have a positive effect on FIW, it is also not surprising that family involvement would have a positive effect on WIF. However, previous research has failed to address this type of relationship. It would make sense that if an individual was highly involved in one domain, that it may interfere with carrying out the responsibilities of another domain (or that spillover would occur from the domain of higher involvement into the domain of lesser involvement). This assumes, however, that being highly involved in one domain also means that the responsibilities of that domain take precedence over responsibilities of the other domain. For 
example, if a woman displayed a high level of family involvement, then it would be reasonable to assume that the family responsibilities would be more important (or more salient) to her than her work responsibilities. However, it has not been addressed by the research as to why it would be that the same woman (highly involved within the family domain) would experience WIF, or that responsibilities from the domain of lesser involvement would interfere with the domain of higher involvement, although it does make intuitive sense. The issue of choice seems to have been neglected in the research. For instance, working is not a choice for most people, rather it is a means for survival. Some individuals may or may not actually choose to become highly involved in a role, which could have an effect on how conflict between roles is perceived. It is apparent that there is still some mystery as to how the work and family roles affect each other.

Based on previous research findings that social support has been associated with lower levels of WFC (Burke, 1988; Goff et al., 1990; Higgins \& Duxbury, 1992), and that buffering effects of social support have been found for various relationships between stressors and stress (Abbey et al., 1985; Etzion, 1984; Power, 1988), it was hypothesized that social support would moderate the relationship between work involvement and WFC. Social support from partner and social support at work both moderated the relationship of 
work involvement and FIW. Again, it is understandable that partner support would help to alleviate spillover from family to work, but it is less apparent how support at work serves the same function. Furthermore, none of the three sources of social support interacted with work involvement to have any significant effects on WIF. This could suggest that there may be sources of support which were not measured in the present study that may help alleviate WIF, or simply that there are specific types of support (which were not examined with the present study) which are utilized for various types of conflict.

Additionally, it was anticipated that social support would moderate the relationship between family involvement and WFC. Results demonstrated partial support for this hypothesis. Specifically, support from all three sources (partner, friends/relatives, and supervisor/co-workers) each moderated the relationship between family involvement and FIW. Further, social support from supervisor/co-workers moderated the relationship between family involvement and WIF. Therefore, social support seems to play an important role when individuals experience family interference with work, but does not seem to have the same effect when individuals experience work interference with family. The benefits of having a very supportive partner, supportive friends/relatives, and a great deal of support at work for an individual who is highly involved in the family is 
obvious. Due to the fact that when individuals receives a great deal of support from these sources, they may not have to worry about family responsibilities so much and can therefore, concentrate fully on work responsibilities while at work. Likewise, the importance of having a supportive boss and/or co-workers in reducing WIF when an individual is highly involved in the family role is also understandable. This suggests that support received in the workplace may help to alleviate the pressures at work, allowing for the individual to focus more attention on the family domain, or at least prevent the individual from allowing work issues to interfere with the family. The above findings possibly suggest that support from the domain where conflict originates may be more beneficial than support received from another domain. However, more research will need to be conducted in order to examine these relationships.

Finally, it was speculated that moderating effects of social support would be more evident for women than for men, since it has been suggested that women are more likely to seek out support, receive support, and be pleased with the support that they receive (Belle, 1987). Further, the number of women working outside the home is increasing, while women still carry a great deal of the family responsibilities (Duxbury \& Higgins, 1991). In addition, it has been suggested that the familial role is more prominent for women than for men (Parasuraman et al., 1992) and that 
there exists a greater interdependence between work and family spheres for women (Greenglass et al., 1988). Results from the present study indicated that social support from supervisor/co-workers did serve to moderate the relationship between family involvement and WIF for women only, but this result was not significantly different from the male sample. There were also several moderating effects demonstrated for only the males, and several moderating effects for both genders. However, none of these relationships differed significantly between genders. It should also be noted that support perceptions were the focus of the support measure, not actual support. There may be gender biases with respect to how support is perceived and whether or not it is even recognized as support. Further research will need to be conducted in order to determine exactly what effects gender has on these complex relationships.

Limitations of the Present Study

There are several limitations to the present study. As mentioned earlier, there may have been problems with the survey, such as confusing terminology and the ordering of items within the survey. In addition, further research in this area should examine levels of involvement and levels of WFC of the partners as well, in order to obtain a broader scope of the nature of how individuals deal with conflict originating in the work and family domains. Furthermore, the current sample was limited to a university setting, and 
therefore, results cannot be generalized to other populations without further research.

Another area of limitation surrounds the measurement and conceptualization of social support. Although social support was measured from various sources, different types of support were not addressed, nor did we obtain any information with regard to social networks. Due to constraints with respect to time and length of the measurement instrument, our priorities fell with measuring source of support over type of support, although it is recognized that assessing type of support is equally important. There has been a great deal of speculation within the social support literature as to the purpose that social support may serve. It has been suggested that buffering properties may only become evident in the presence of stress (Caplan, 1974; Cohen \& Wills, 1985). Although buffering effects were demonstrated in the present study between the relationship of involvement and WFC, it should be noted that this relationship was less evident at low levels of involvement, such that there was little or no effect of social support when involvement was low.

It is evident that there are inherent problems with studying the phenomenon of social support. First of all, there needs to be some agreement on the operationalization of the term, including categories of the specific types of social support. With the amount of disagreement present, it 
is not surprising that research has yielded such mixed results with respect to the possible effects that social support may have on various relationships. There is some speculation, however, that the skepticism regarding the buffering effect of social support could be diminished by well-designed research and appropriate analyses (Koeske \& Koeske, 1991). These authors contend that more powerful statistical procedures should be used to examine buffering effects, that conceptual models and measures of social support need to be better developed, that more specific stress measures should be used, and that there may be other factors present which may cancel out a buffering effect. In general, the argument is that previous researchers have not been addressing this topic in an appropriate manner.

Cohen and Wills (1985) have provided an exhaustive review of the social support literature through 1984. The authors examined and compared numerous studies on the effects of social support, and found evidence for both main effects and buffering effects. Specifically, evidence for buffering was found when the availability of social support was assessed in response to stressful events. On the other hand, evidence for a main effect of social support was found when support was measured by the degree to which an individual was integrated into a social network. This may very well be the case. Although the present study did not measure stress levels, the social support measure used was 
geared toward assessing whether or not individuals perceived that they would have support available to them when it was needed (i.e., when they feel overloaded, when things get tough). Therefore, according to Cohen and Wills, the moderating effects demonstrated by the present study could simply be due to the nature of the measurement instrument.

Another limitation of the present study may have been the criteria used to reduce the sample for the present analyses. As previously mentioned, since WFC was a focus of this study, only those who worked over 20 hours per week and had either a partner or a child were analyzed. This criteria was chosen as a means of obtaining individuals who may have difficulty balancing work and family roles simultaneously. However, there may be a significant difference between the level of conflict perceived by an individual who has a partner, but no children and an individual who has a child, but no partner. Further, the present study did not address the number of children that the respondents had, which would no doubt have a significant effect on the amount of conflict perceived.

\section{Alternative Issues and Explanations}

There were several variables from the survey which may have had effects on the relationships which were examined. For example, university status was assessed (i.e., faculty, staff, student), as well as job classification (e.g., technical, professional, service), but not controlled for. 
It may be that levels of involvement and levels of conflict may differ greatly between faculty and students, and between various levels of occupations. Age may also affect how an individual perceives conflict and may have an effect on the level of involvement which is expended in the work and family domains. As individuals age, they may discover ways in which to manage conflict between work and family roles. In addition, work schedule flexibility may have an effect on perceived level of conflict, such that a schedule which allows a great deal of flexibility may result in less conflict between roles.

The issues and relationships which were examined in the present study are very sensitive to context, and perhaps a university setting was not an appropriate arena for examination. For example, students may have different support mechanisms for balancing their various roles, and as mentioned earlier, the issues surrounding WFC become even less clear for an individual who is balancing work, family, and school.

\section{Future Research}

A great deal of research has been conducted in the area of social support, but there has been no agreement as to what the operational definition should be. Although there is a host of categories used to define types of social support, Barrera and Ainlay (1983) contend that they all seem to be subcategories of two types of support, emotional 
and practical. House (1981), on the other hand, suggests four types of support including informational, instrumental, emotional, and appraisal. Others have examined social support in terms of social relationships, specifically their quantity, structure, and function (House \& Kahn, 1985; House, Umberson, \& Landis, 1988). Structure refers to the characteristics of social networks such as density, reciprocity, durability, size, and intensity. The functional aspect refers to the degree to which types of support are being exchanged, such as tangible aid or information/advice. House and Kahn suggest that at least two of the aspects, if not all three, should be measured within a single study in order to truly assess social support and the function that it serves.

A majority of the social support research has been within the area of stress and health. The present study intended to expand this research to other areas where social support may serve as a buffer, specifically the relationship between involvement and WFC. It seemed reasonable to assume that a buffering effect would be found, since receiving support should help to ease the pressures of overwhelming responsibilities felt by those individuals who are attempting to balance many roles simultaneously. Further research, however, should focus on more specific types of support from various sources, and utilize more specific measures in order to address the various aspects of social 
relationships and social networks that were outlined by House and Kahn (1985). Also, there needs to be further examination of which types of support from which sources help to alleviate both types of WFC (WIF and FIW). There is some evidence to suggest that support from a source within the domain where stress is experienced may be more beneficial than support from other sources (Parasuraman, et al., 1992) .

One notion that often seems to be overlooked within the social support literature is the fact that social support may not always be helpful. There may be costs associated with social support. For instance, individuals may feel uncomfortable in accepting offered support due to feelings of obligation, or feeling that they owe the person something in return. Etzion (1984) suggested that the process of developing and maintaining social relationships beyond an individual's need may be a very stressful in itself. Furthermore, Belle (1987) noted that social networks may heighten psychological distress when members display disrespect or disapproval, betray confidences, or fail to fulfill expectations. Therefore, it may be of interest to measure individuals' perceptions as to which types of support from which sources would be beneficial in helping to alleviate WFC, and which types of support may actually be detrimental.

It is evident that the possible relationships between 
work and family involvement, social support, and WFC are very complex and require further examination using more specific measurement instruments. In addition, the variables themselves need more specific conceptualization and operationalization in order to determine exactly how they interact and under which circumstances. There is a need for future research on the theories surrounding the work and family domains. Based on previous research the present study examined work and family involvement as predictors of WFC. However, present results indicated that these variables only accounted for a small portion of the variance in WFC. Perhaps more qualitative research should be conducted in order to better define the constructs, resulting in more precise measures. 


\section{References}

Abbey, A., Abramis, D. J., \& Caplan, R. D. (1985). Effects of different sources of social support and social conflict on emotional well-being. Basic and Applied Social Psychology, 6, 111-129.

Barrera, M., \& Ainlay, S. L. (1983). The structure of social support: A conceptual and empirical analysis. Journal of Community Psychology, 11, 133-143.

Bedeian, A. G., Burke, B. G., \& Moffett, R. G. (1988). Outcomes of work-family conflict among married male and female professionals. Journal of Management, 14, 475-491.

Belle, D. (1987). Gender differences in the social moderators of stress. In: R. C. Barnett, L. Biener, \& G. K. Baruch (Eds.), Gender and stress. (pp. 257-277). New York: Free Press.

Beutell, N. J., \& Greenhaus, J. H. (1982). Interrole conflict among married women: The influence of husband and wife characteristics on conflict and coping behavior. Journal of Vocational Behavior, 21, 99-110.

Burda, P. C., \& Vaux, A. C. (1987). The social support process in men: Overcoming sex-role obstacles. Human Relations, 40, 31-44.

Burke, R. J. (1988). Some antecedents and consequences of work-family conflict. Journal of Social Behavior and Personality, 3, 287-302.

Caplan, G. (1974). Support systems and community 
mental health. New York, New York: Behavioral Publications.

Caplan, R. D., Cobb, S., French, J. R. P., Jr., Van Harrison, R., \& Pinneau, S. R., Jr. (1975). Job Demands and Worker Health. U. S. Department of Health, Education, and Welfare, Publication No. (NIOSH) 75-160.

Cohen, S., \& Wills, T.A. (1985). Stress, social support, and the buffering hypothesis. Psychological Bulletin, 98, 310-357.

Duxbury, L. E., \& Higgins, C. A. (1991). Gender differences in work-family conflict. Journal of Applied Psychology, 76, 60-74.

Engels, F. (1892). The condition of the working class in England in 1844. (F. K. Wischnewetsky, Trans.). London: Allen \& Unwin, Ltd.

Evans, P., \& Bartolome, F. (1984). The changing pictures of the relationships between career and family. Journal of Occupational Behavior, $5,9-21$.

Etzion, D. (1984). Moderating effect of social support on the stress-burnout relationship. Journal of Applied Psychology, 69, 615-622.

Frone, M. R., \& Rice, R. W. (1987). Work-family conflict: The effect of job and family involvement. Journal of occupational Behavior, $8,45-53$.

Frone, M. R., Russell, M. \& Cooper, M. I. (1991). Relationship of work and family stressors to psychological 
distress: The independent moderating influence of social support, mastery, active coping, and self-focused attention. Journal of Social Behavior and Personality, 6, 227-250.

Frone, M. R., Russell, M., \& Cooper, M. L. (1992). Antecedents and outcomes of work-family conflict: Testing a model of the work-family interface. Journal of Applied Psychology, 77, 65-78.

Goff, S. J., Mount, M. K., \& Jamison, R. L. (1990). Employer supported child care, work/family conflict, and absenteeism: A field study. Personnel Psychology, 43, 793809 .

Greenglass, E. R., Pantony, K., \& Burke, R. J. (1988). A gender-role perspective on role conflict, work stress and social support. Journal of Social Behavior and Personality, 3. $317-328$.

Greenhaus, J. H., \& Beutell, N. J. (1985). Sources of conflict between work and family roles. Academy of Management Review, 10, 76-88.

Greenhaus, J. H., Parasuraman, S., Granrose, C. S., Rabinowitz, S., \& Beutell, N. J. (1989). Sources of workfamily conflict among two-career couples. Journal of Vocational Behavior, 34, 133-153.

Gutek, B. A., Searle, S., \& Klepa, L. (1991). Rational versus gender role explanations for work-family conflict. Journal of Applied Psychology, 76, 560-568.

Higgins, C. A., \& Duxbury, L. E. (1992). Work-family 
conflict: A comparison of dual-career and traditionalcareer men. Journal of Organizational Behavior, 13, 389411 .

Higgins, C. A., Duxbury, L. E., \& Irving, R. H. (1992). Work-family conflict in the dual-career family.

Organizational Behavior and Human Decision Processes, 51. $51-75$.

House, J. S. (1981). Work stress and social support. Reading, MA: Addison-Wesley.

House, J. S., \& Kahn, R. L. (1985). Measures and concepts of social support. In S. Cohen \& S. L. Syme (Eds.), Social Support and Health (pp. 83-108). Orlando, FL: Academic Press.

House, J. S., Umberson, D., \& Landis, K. R. (1988). Structures and processes of social support. Annual Review of Sociology, 14, 293-318.

Kahn, R. I., Wolfe, D. M., Quinn, R., Snoek, J. D., \& Rosenthal, R. A. (1964). organizational stress: Studies in role conflict and ambiguity. New York: Wiley.

Kanungo, R. N. (1979). The concepts of alienation and involvement revisited. Psychological Bulletin, $1,119-138$. Kelly, R. F., \& Voydanoff, P. (1985). Work/family role strain among employed parents. Journal of Applied Psychology, 34, 367-374.

Koeske, G. F., \& Koeske, R. D. (1991). Underestimation of social support buffering. Journal of Applied Behavioral 
Science, $27,475-489$.

Kopelman, R. E., Greenhaus, J. H., \& Connolly, T. F.

(1983). A model of work, family, and interrole conflict: A construct validation study. Organizational Behavior and Human Performance, 32, 198-215.

Lin, N., Simeone, R., Ensel, W., \& Kuo, W. (1979). Social support, stressful life events and illness: A model and an empirical test. Journal of Health and Social Behavior, 20, 108-119.

Loscocco, K. A., \& Spitze, G. (1990). Working conditions, social support, and the well-being of female and male factory workers. Journal of Health and Social Behavior, 31, 313-327.

Marshall, N. L., \& Barnett, R. C. (1992). Work-related support among women in caregiving occupations. Journal of Community Psychology, 20, 36-42.

Misra, S., Ghosh, R., \& Kanungo, R. N. (1990).

Measurement of family involvement. Journal of CrossCultural Psychology, 21, 232-248.

Parasuraman, S., Greenhaus, J. H., \& Granrose, C. S. (1992). Role stressors, social support, and well-being among two-career couples. Journal of Organizational Behavior, 13, 339-356.

Pleck, J. H. (1977). The work-family role system. Social Problems, 24, 417-426.

Pleck, J. H., Staines, G. L., \& Lang, L. (1980). 
Conflicts between work and family life. Monthly Labor Review, 103, 29-32.7

Power, M. J. (1988). Stress-buffering effects of social support: A longitudinal study. Motivation and Emotion, 12, 197-204.

Reifman, A., Biernat, M., \& Lang, E. L. (1991). Stress, social support, and health in married professional women with small children. Psychology of Women ouarterly, 15. $431-445$

Schor, J. (1991). The Overworked American: The Unexpected Decline of Leisure. Washington, D. C. : Basic Books.

Sokoloff, N. J. (1980). Between money and love. New York: Praeger Publishers.

Vaux, A., \& Athanassopulou, M. (1987). Social support appraisals and network resources. Journal of Community Psychology, 15, 537-556.

Wilensky, H. L. (1960). Work, careers, and social integration. International Social Science Journal, 12, 543560 .

Yogev, S., \& Brett, J. (1985). Patterns of work and family involvement among single- and dual-earner couples. Journal of Applied Psychology, 70, 754-768.

Zaretsky, E. (1976). Capitalism, the family, \& personal life, New York: Harper \& Row.

Zedeck, S., \& Mosier, K. L. (1990). Work in the family 
and employing organization. American Psychologist, 45, 240251 . 
Table 1

Summary Statistics and Correlations for Measurement scales

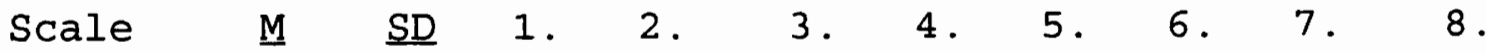

Involvement
1. WI
$2.82 \quad .65(.73)$
2. FI
$3.87 \quad .82 \quad .17 *(.86)$

Social Support
3. Part $4.39 \quad .91 \quad-.03 \quad .01 \quad(.95)$
4. Sup/ $\begin{array}{lllllll}3.75 & .84 & -.02 & .03 & .09 & (.90)\end{array}$

5. Fr/ $4.03 \quad .74-.15 *-.05 \quad .23 * * .38 * * \quad(.91)$

Relatives

WFC

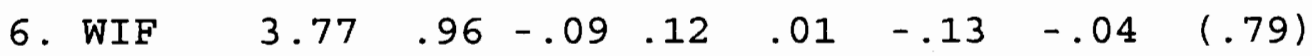

7. FIW $2.12 \quad .84 \quad .08 \quad .16 *-.08-.16 *-.15 * .37 * \star \quad .66)$

8. Ease $3.111 .25-.08 .02-.15 *-.16 *-.13 \quad .45 * * .29 *$ *

Note. Coefficient alpha's for each scale are given in parentheses. "Ease" refers to item \#22 on the survey, which assesses the ease with which participants handled work and family demands. WIF = work interference with family; FIW = family interference with work. Responses for the above scales ranged from 1 to 5 , with the exception of the "Ease" item which had a range from 1 to 6 .

${ }^{\star} \mathrm{p}<.05 ; \star \star \mathrm{p}<.01$. 
Table 2

Rotated Factor Loadings on Involvement Scale Items

\begin{tabular}{|c|c|c|c|c|}
\hline & & Factor 1 & Factor 2 & Factor 3 \\
\hline \multirow{5}{*}{$\begin{array}{l}\text { Family } \\
\text { Involvement } \\
\text { Items }\end{array}$} & 1 & .72 & -.22 & -.11 \\
\hline & 2 & .86 & -.07 & -.13 \\
\hline & 3 & .89 & -.07 & -.09 \\
\hline & 4 & .86 & -.09 & -.03 \\
\hline & 5 & .73 & -.08 & .23 \\
\hline (absorb) & 6 & .46 & .07 & .76 \\
\hline \multirow{5}{*}{$\begin{array}{l}\text { Work } \\
\text { Involvement } \\
\text { Items }\end{array}$} & 1 & -.03 & .69 & .23 \\
\hline & 2 & .42 & .53 & -.43 \\
\hline & 3 & .23 & .73 & -.41 \\
\hline & 4 & .07 & .78 & -.05 \\
\hline & 5 & -.09 & .77 & .04 \\
\hline (absorb) & 6 & .09 & .45 & .67 \\
\hline Eigenvalue & & 3.78 & 2.77 & 1.52 \\
\hline
\end{tabular}

Note. The two items denoted above as "(absorb)" are the two which resulted in the third factor. Total variance accounted for by the two factors $=67.6 \%$. 
Table 3

Rotated Factor Loadings on Social support scale Items

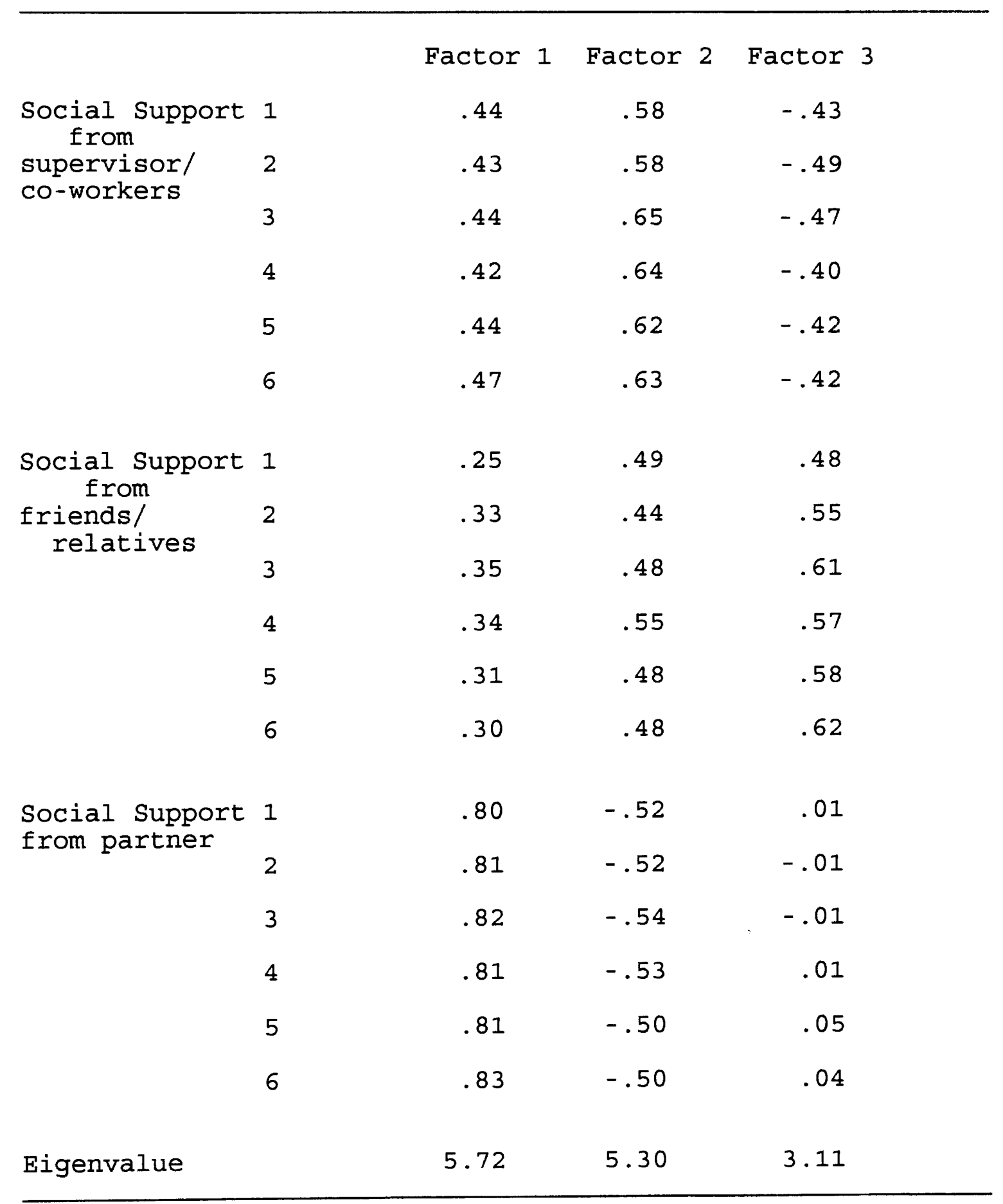

Note. Total variance accounted for $=79.5 \%$. 
Table 4

Rotated Factor Loadings on WFC Items

\begin{tabular}{lrrr}
\hline & & Factor 1 & Factor 2 \\
WIF Items & 1 & .76 & .01 \\
& 2 & .68 & .14 \\
& 3 & .79 & -.02 \\
& 4 & .81 & .02 \\
FIW Items & 1 & -.20 & .69 \\
& 2 & .09 & .73 \\
& 3 & .49 & .56 \\
& 4 & .14 & .83 \\
Eigenvalue & & & 1.81 \\
\hline
\end{tabular}

Note. Total variance accounted for by the two factors = $58.2 \%$. 
Table 5

Multiple Regressions for Involvement and Social support from Friends/Relatives, and Their Interactions predicting FIW

\begin{tabular}{ccc}
\hline IV & Beta & $\underline{\Delta R}^{2}$ \\
Work Involvement & .04 & \\
Family Involvement & $.15 *$ & $.05 *$ \\
Social Support & -.13 & \\
& & .00 \\
WI x Soc. Supp. & .06 & $.01 *$ \\
& .97 & \\
FI X Soc. Supp. & & $.01 *$ \\
& & \\
\hline WI x Soc. Supp. & 1.00 & \\
\hline
\end{tabular}

Note. ${ }^{\star} \underline{\underline{p}}<.05 ;{ }^{\star} \underline{\mathrm{P}}<.01 ; \mathrm{R}$ for full model $=.25 \quad \underline{\mathrm{F}}=2.60$, $D=.03)$. Step 1 = enter both involvement terms and social support; Step $2 \mathrm{a}=$ enter interaction term of work involvement and social support; step $2 \mathrm{~b}=$ enter interaction term of family involvement and social support; step $3=$ enter both interaction terms of involvement and support. 
Table 6

Multiple Regressions for Involvement and Social support from Partner, and Their Interactions predicting FIW

\begin{tabular}{ccc}
\hline IV & Beta & $\Delta R^{2}$ \\
Work Involvement & .05 & \\
Family Involvement & $.15 *$ & .03 \\
Social Support & -.08 & \\
& & $.02 *$ \\
WI x Soc. Supp. & -.97 & $.03 *$ \\
& $1.41 *$ & \\
FI x Soc. Supp. & & $.04 *$ \\
& $1.40 *$ & \\
\hline FI $\times$ Soc. Supp. & & \\
\hline
\end{tabular}

Note. ${ }^{*} \mathrm{P}<.05 ; * *_{\mathrm{Q}}<.01 ; \mathrm{R}$ for full model $=.27 \quad(\underline{F}=3.14$, $\underline{Q}=.01$ ). Step 1 = enter both involvement terms and social support; step $2 \mathrm{a}=$ enter interaction term of work involvement and social support; step $2 \mathrm{~b}=$ enter interaction term of family involvement and social support; step $3=$ enter both interaction terms of involvement and support. 
Table 7

Multiple Regressions for Involvement and Social Support from Supervisor/Co-workers, and Their Interactions Predicting FIW

\begin{tabular}{|c|c|c|}
\hline$\underline{I V}$ & Beta & $\Delta \mathrm{R}^{2}$ \\
\hline Work Involvement & .05 & \\
\hline Family Involvement & $.15 *$ & \\
\hline Social Support & $-.16 *$ & $.05 *$ \\
\hline WI $\mathbf{x}$ SOC. Supp. & -.36 & $.01 *$ \\
\hline FI x Soc. Supp. & -.58 & $.01 *$ \\
\hline WI x Soc. Supp. & -.21 & \\
\hline FI x Soc. Supp. & -.52 & $.01 *$ \\
\hline
\end{tabular}

Note. ${ }^{*} \underline{p}<.05 ; * * \underline{p}<.01 ; R$ for full model $=.25 \quad \underline{\underline{F}}=2.68$, $\underline{Q}=.02)$. Step 1 = enter both involvement terms and social support; Step $2 \mathrm{a}=$ enter interaction term of work involvement and social support; step $2 \mathrm{~b}=$ enter interaction term of family involvement and social support; step $3=$ enter both interaction terms of involvement and support. 
Table 8

Multiple Regressions for Involvement and Social support from Friends/Relatives, and Their Interactions Predicting WIF

\begin{tabular}{|c|c|c|}
\hline IV & Beta & $\Delta \mathrm{R}^{2}$ \\
\hline Work Involvement & -.12 & \\
\hline Family Involvement & .14 & \\
\hline Social Support & -.05 & .03 \\
\hline WI x SOC. Supp. & .41 & .00 \\
\hline FI x Soc. Supp. & -.06 & .00 \\
\hline WI $\mathbf{x}$ Soc. Supp. & .44 & \\
\hline FI $x$ Soc. Supp. & -.17 & .00 \\
\hline
\end{tabular}

Note. ${ }^{*} \underline{\underline{p}}<.05 ; * \star \underline{\mathrm{D}}<.01 ; \mathrm{R}$ for full model $=.18 \quad(\underline{F}=1.37$, $\mathrm{P}=.24)$. Step 1 = enter both involvement terms and social support; step $2 \mathrm{a}=$ enter interaction term of work involvement and social support; Step $2 \mathrm{~b}=$ enter interaction term of family involvement and social support; step $3=$ enter both interaction terms of involvement and support. 
Table 9

Multiple Regressions for Involvement and Social support from Partner, and Their Interactions Predicting WIF

\begin{tabular}{|c|c|c|}
\hline IV & Beta & $\Delta \mathrm{R}^{2}$ \\
\hline Work Involvement & -.11 & \\
\hline Family Involvement & $.14 *$ & \\
\hline Social Support & .00 & .03 \\
\hline WI $\mathrm{x}$ Soc. Supp. & -.30 & .00 \\
\hline FI $x$ Soc. Supp. & -.19 & .00 \\
\hline WI $x$ Soc. Supp. & -.30 & \\
\hline FI x Soc. Supp. & -.19 & .00 \\
\hline
\end{tabular}

Note. ${ }^{*} \underline{p}<.05 ; * * \underline{p}<.01 ; R$ for full model $=.17(\underline{F}=1.14$, $\underline{p}=.34)$. Step 1 = enter both involvement terms and social support; Step $2 a=$ enter interaction term of work involvement and social support; step $2 \mathrm{~b}=$ enter interaction term of family involvement and social support; Step $3=$ enter both interaction terms of involvement and support. 
Table 10

Multiple Regressions for Involvement and Social Support from Supervisor/Co-workers, and Their Interactions Predicting WIF

\begin{tabular}{ccc}
\hline IV & Beta & $\Delta \mathrm{R}^{2}$ \\
Work Involvement & -.11 & \\
Family Involvement & $.14^{*}$ & $.04^{*}$ \\
Social Support & -.13 & \\
\hline WI x Soc. Supp. & .16 & .00 \\
& & $.01 *$ \\
FI x Soc. Supp. & -.53 & \\
& & .01 \\
WI x Soc. Supp. & -.63 & \\
\hline FI x Soc. Supp. & & \\
\hline
\end{tabular}

Note. ${ }^{*} \underline{p}<.05 ; * \star Q R<.01 ; R$ for full model $=.23 \quad(\underline{F}=2.18$, $Q=.06)$. Step 1 = enter both involvement terms and social support; Step $2 \mathrm{a}=$ enter interaction term of work involvement and social support; step $2 \mathrm{~b}=$ enter interaction term of family involvement and social support; Step $3=$ enter both interaction terms of involvement and support. 
Table 11

Interaction Effects of Social support on the Relationships Between Work and Family Involvement and FIW

\begin{tabular}{|c|c|c|c|c|}
\hline \multirow[b]{2}{*}{ Interaction Terms } & \multicolumn{2}{|c|}{ Men } & \multicolumn{2}{|c|}{ Women } \\
\hline & $\mathrm{R}^{2}$ & $F$ & $\mathrm{R}^{2}$ & $\mathrm{~F}$ \\
\hline$F I \times S S p$ & $.02 \star$ & 3.08 & $.02 *$ & 9.14 \\
\hline FI $x$ SSSV & $.01 *$ & 2.13 & $.01 \star$ & 3.41 \\
\hline FI $x \operatorname{sSfr}$ & $.04 * \star$ & 5.53 & .01 & 1.56 \\
\hline WI $x$ SSp & $.03 *$ & 3.86 & $.04 *$ & 13.77 \\
\hline WI $x$ SSsV & $.02 *$ & 1.83 & .00 & .54 \\
\hline WI $x$ SSfr & $.01 \star \star$ & 1.86 & .00 & .83 \\
\hline
\end{tabular}

Note. $F I=$ family involvement $; \mathrm{WI}=$ work involvement $; \mathrm{sSp}=$ social support from partner; SSsv = social support from supervisor/co-workers; Ssfr = social support from friends/relatives.

${ }^{*} \underline{p}<.05 ; * \star \underline{p}<.01$. 
Table 12

Interaction Effects of Social support on the Relationships Between Work and Family Involvement and WIF

\begin{tabular}{|c|c|c|c|c|}
\hline \multirow[b]{2}{*}{ Interaction Terms } & \multicolumn{2}{|c|}{ Men } & \multicolumn{2}{|c|}{ Women } \\
\hline & $\mathrm{R}^{2}$ & $\mathbf{F}$ & $\underline{\mathrm{R}}^{2}$ & $\mathrm{~F}$ \\
\hline FI $x$ SSp & .01 & 1.16 & .00 & .68 \\
\hline FI $\mathrm{x}$ SSSV & .01 & 1.67 & $.03 *$ & 8.30 \\
\hline FI $x$ SSfr & .03 & 4.08 & .01 & 3.24 \\
\hline WI $\times$ SSp & .01 & 1.31 & .00 & 1.54 \\
\hline WI $\mathrm{x}$ SSsV & .00 & .04 & .01 & .30 \\
\hline WI $\mathrm{x}$ SSfr & .01 & 1.97 & .01 & 1.61 \\
\hline
\end{tabular}

Note. $F I=$ family involvement; $\mathrm{WI}=$ work involvement; $\mathrm{SSp}=$ social support from partner; SSsv = social support from supervisor/co-workers; SSfr = social support from friends/relatives.

$\star \mathrm{p}<.05 ; * \star \mathrm{p}<.01$. 
Figure Caption

Figure 1. Moderating effect of social support from partner on the relationship between work involvement and FIW. 


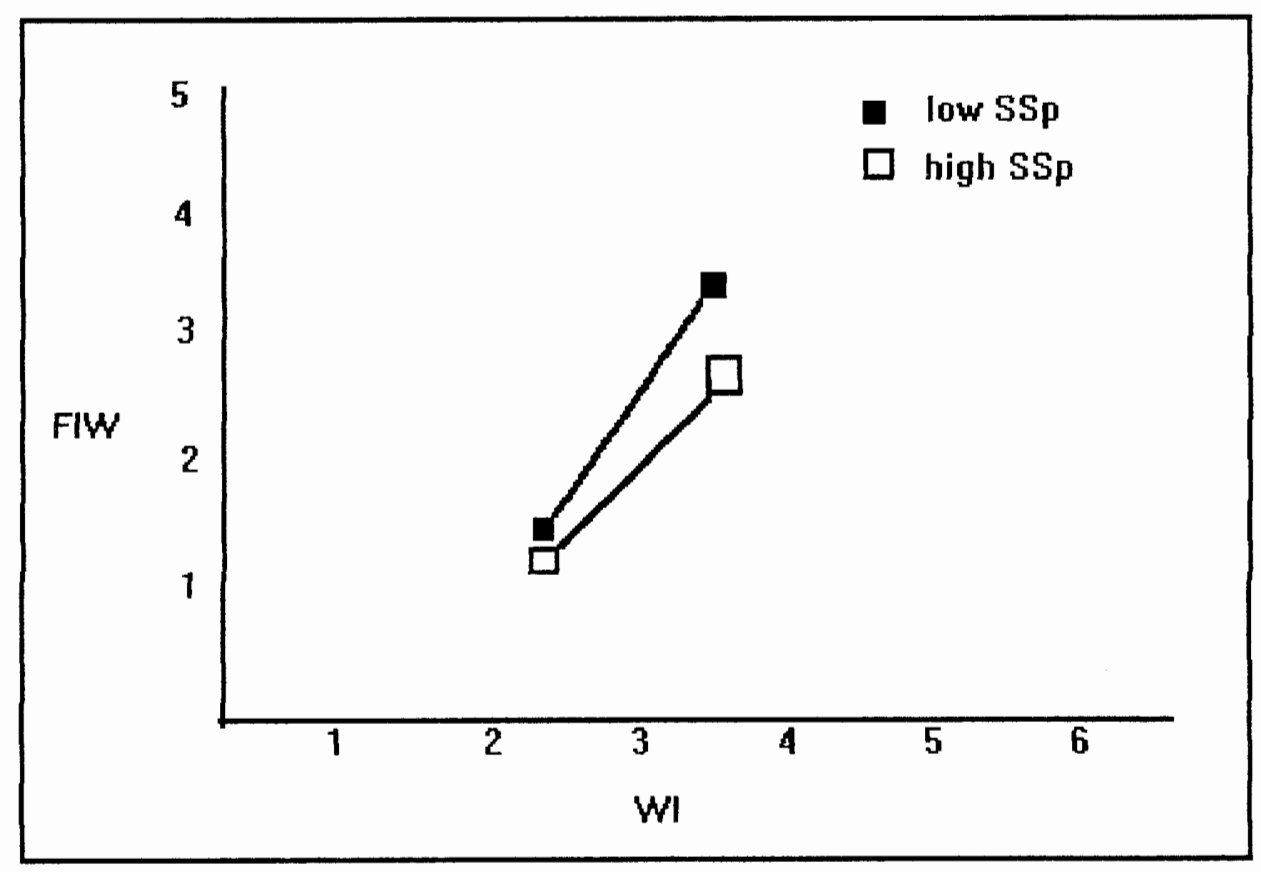


Figure Caption

Figure 2, Moderating effect of social support from supervisor/co-workers on the relationship between work involvement and FIW. 


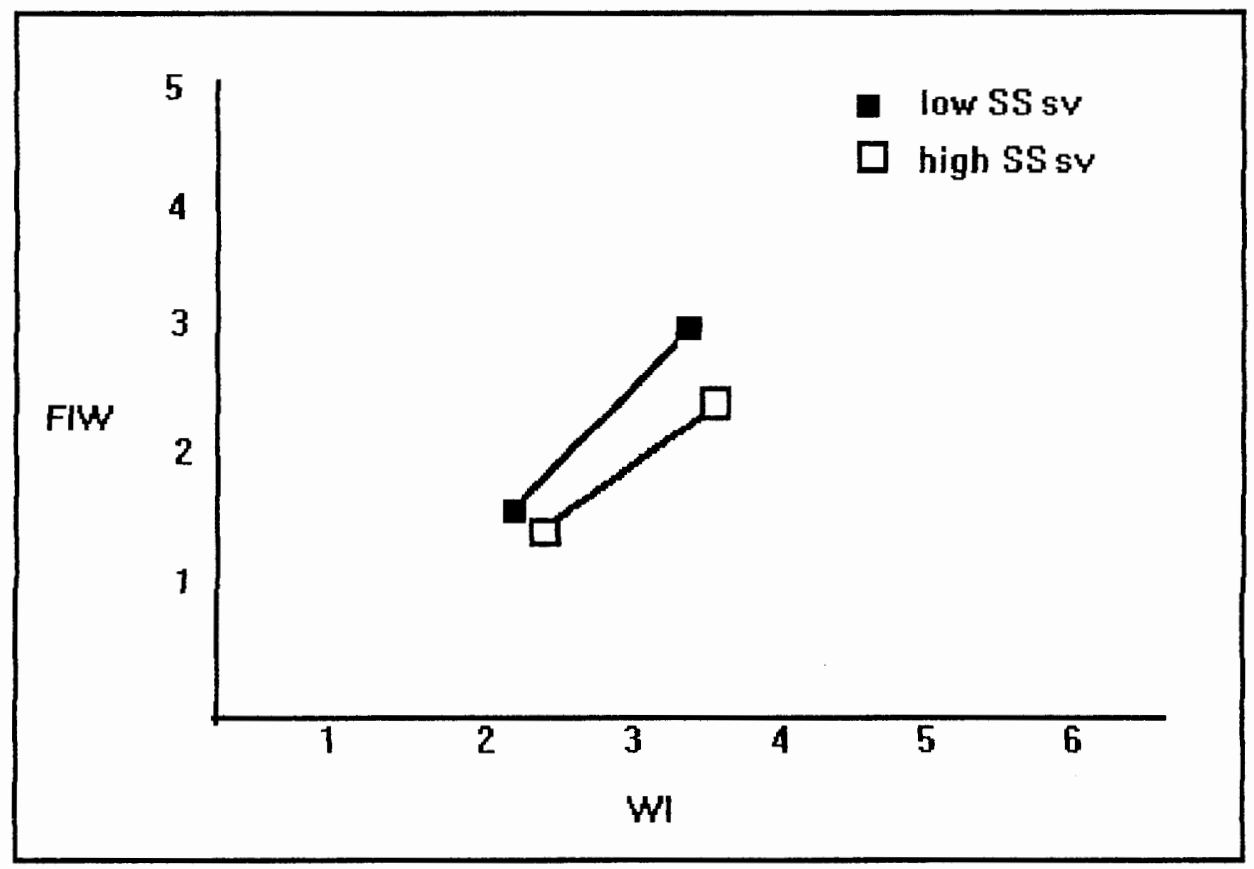


Figure Caption

Figure 3. Moderating effect of social support from

friends/relatives on the relationship between family involvement and FIW. 


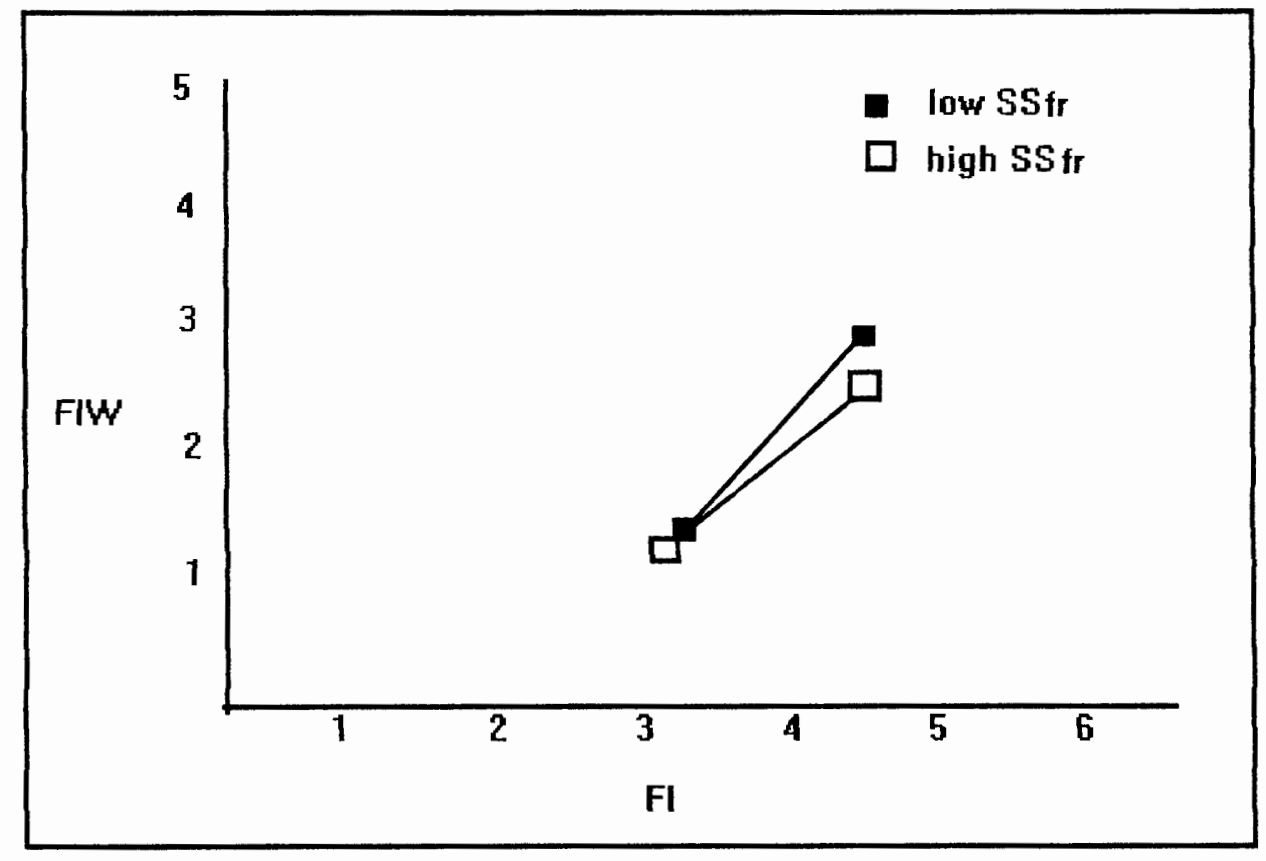


Figure Caption

Figure 4. Moderating effects of social support from partner on the relationship between family involvement and FIW. 


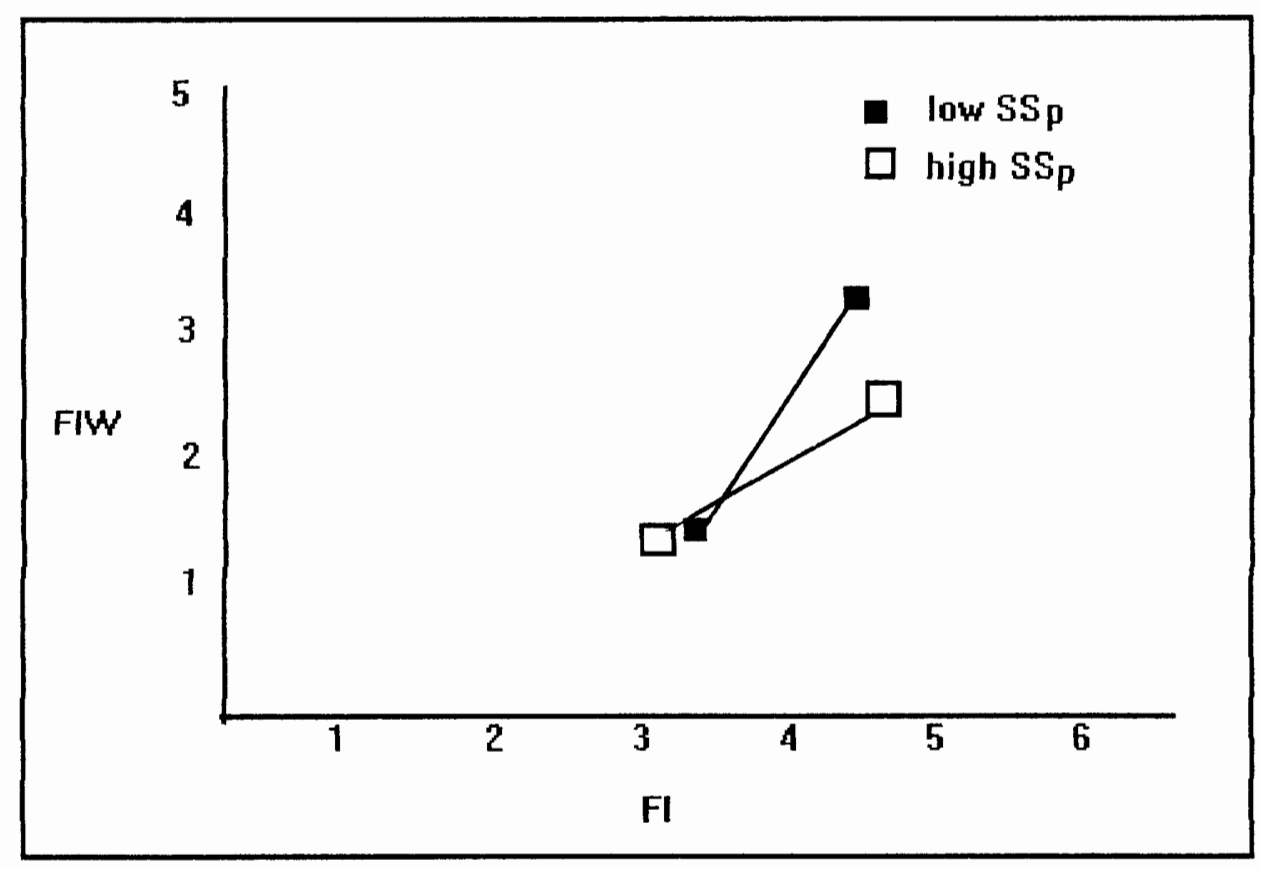


Figure Caption

Figure 5. Moderating effect of social support from supervisor/co-workers on the relationship between family involvement and FIW. 


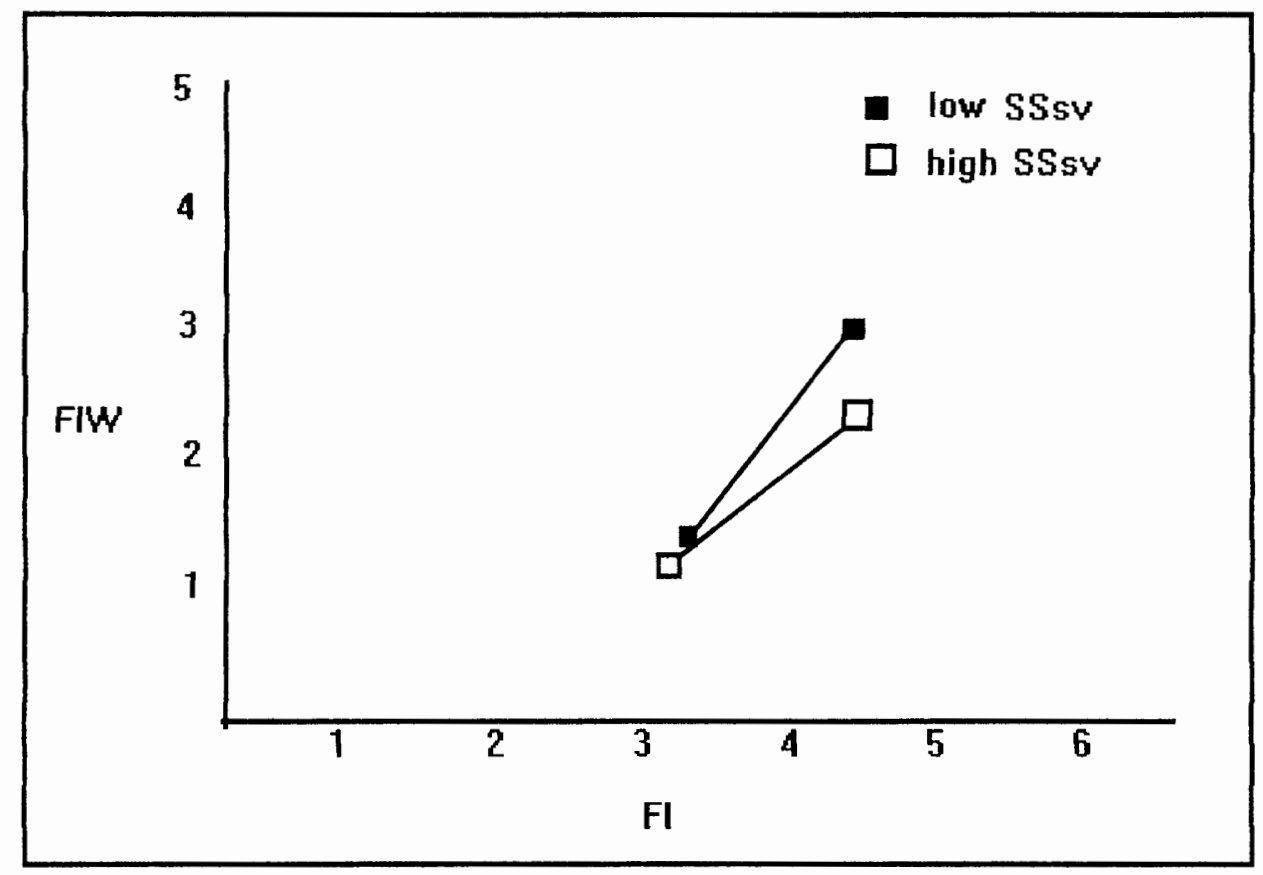


Figure Caption

Figure 6. Moderating effect of social support from supervisor/co-workers on the relationship between family involvement and WIF. 


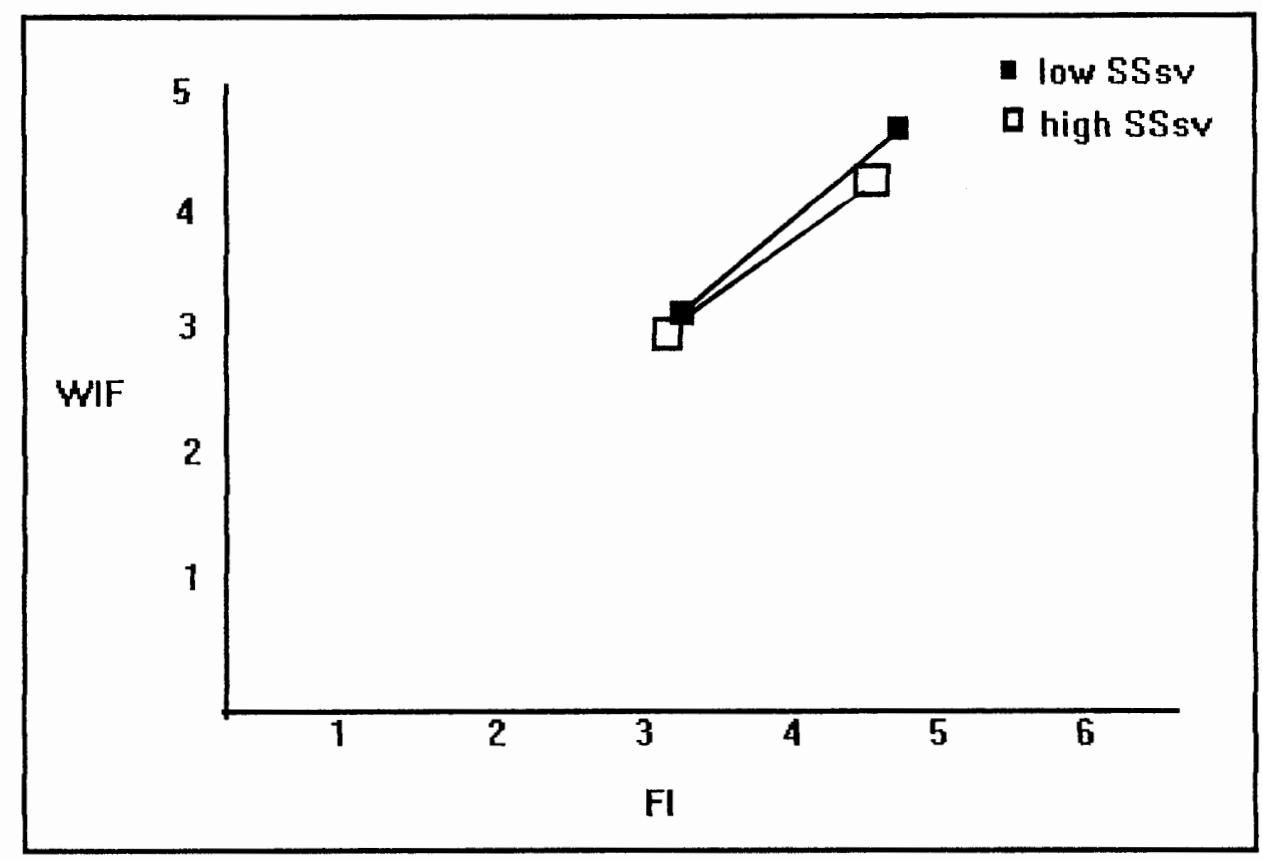


Appendix A 
April 26, 1995

Dear selected member of the campus community --

The PSU Commission on the Status of Women (a commission of students, faculty, and staff) is studying the issue of childcare and family issues on campus. We are interested in better understanding faculty, staff, and student childcare needs, elder care needs, and general concerns about work and family demands.

You have been selected at random to participate in a survey to assess this need on the PSU campus. We are fortunate to have the assistance of a graduate student who is donating time to conduct the survey and analyze the results for us, under the supervision of an academic advisor. In order to further keep costs down, we have selected only a subset of the entire PSU community to survey so your response is particularly important. Please return the survey no later than Monday, May 8.

The survey will serve two purposes. First, the data will provide the Commission with information necessary to make future university policy recommendations. Second, the information will serve as the graduate student's thesis project on work-family conflict and social support. We appreciate the time that you take to complete the survey.

Your participation is voluntary and your responses will be completely anonymous. Results will be reported in aggregate form only. Simply complete the survey, fold it, and return it to the researchers in the Psychology Department via campus mail, using the pre-printed return address. (Please Do NOT tape or staple the survey.)

Thank you for taking the time to complete this important survey. If you have any questions, please feel free to contact either Leslie Hammer, Assistant Professor of Psychology, or Tracy Monzon, graduate student in Psychology, at $(x 5-3971)$.

Thank you for your participation,

PSU President's Commission on the Status of Women (7258299)

If you have any concerns or questions about this study, please contact the Chair of the Human Subjects Review Committee, Office of Research and Sponsored Projects, 105 $\mathrm{NH}, \mathrm{x} 5-3417$. 


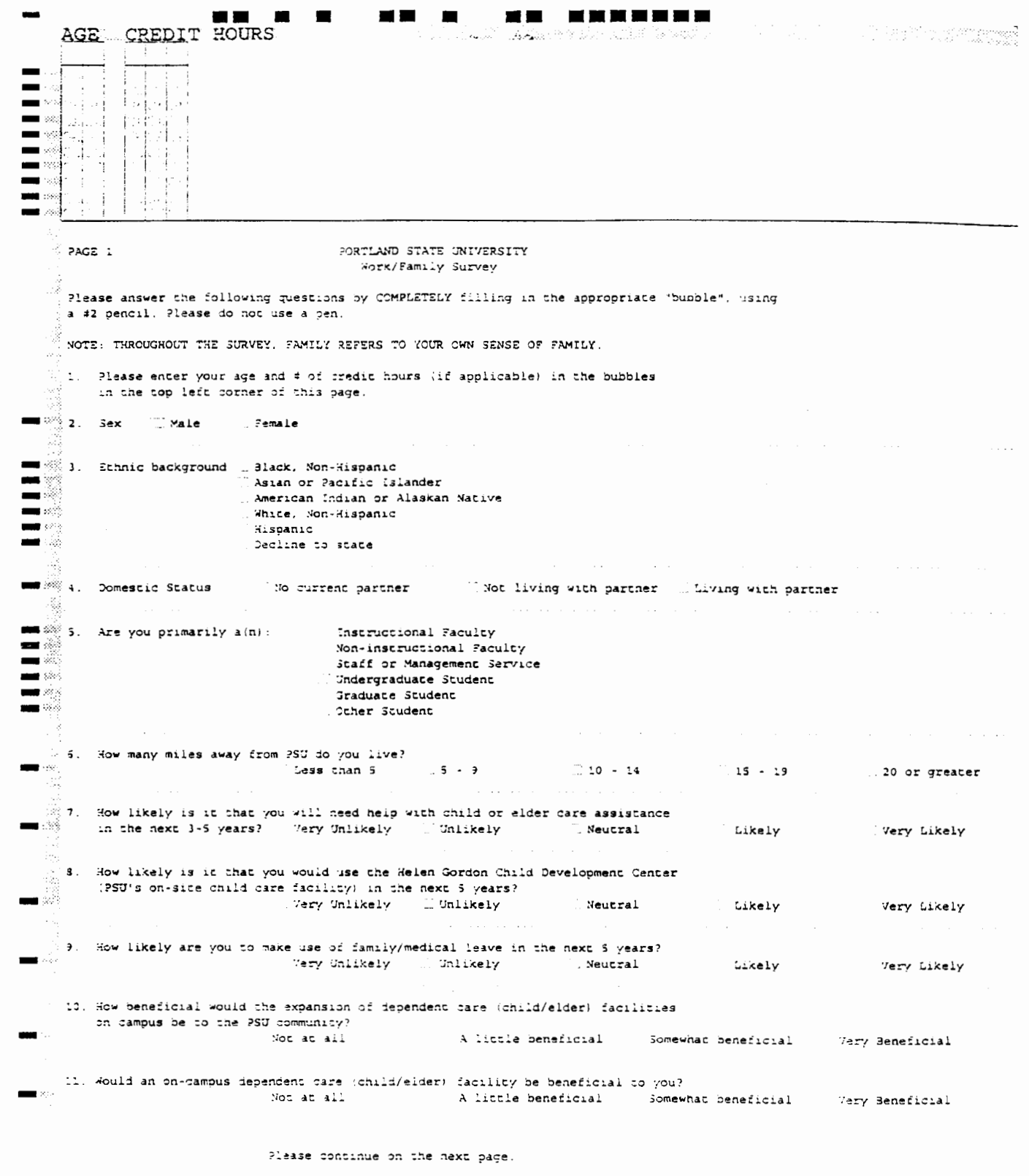

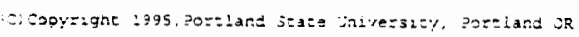




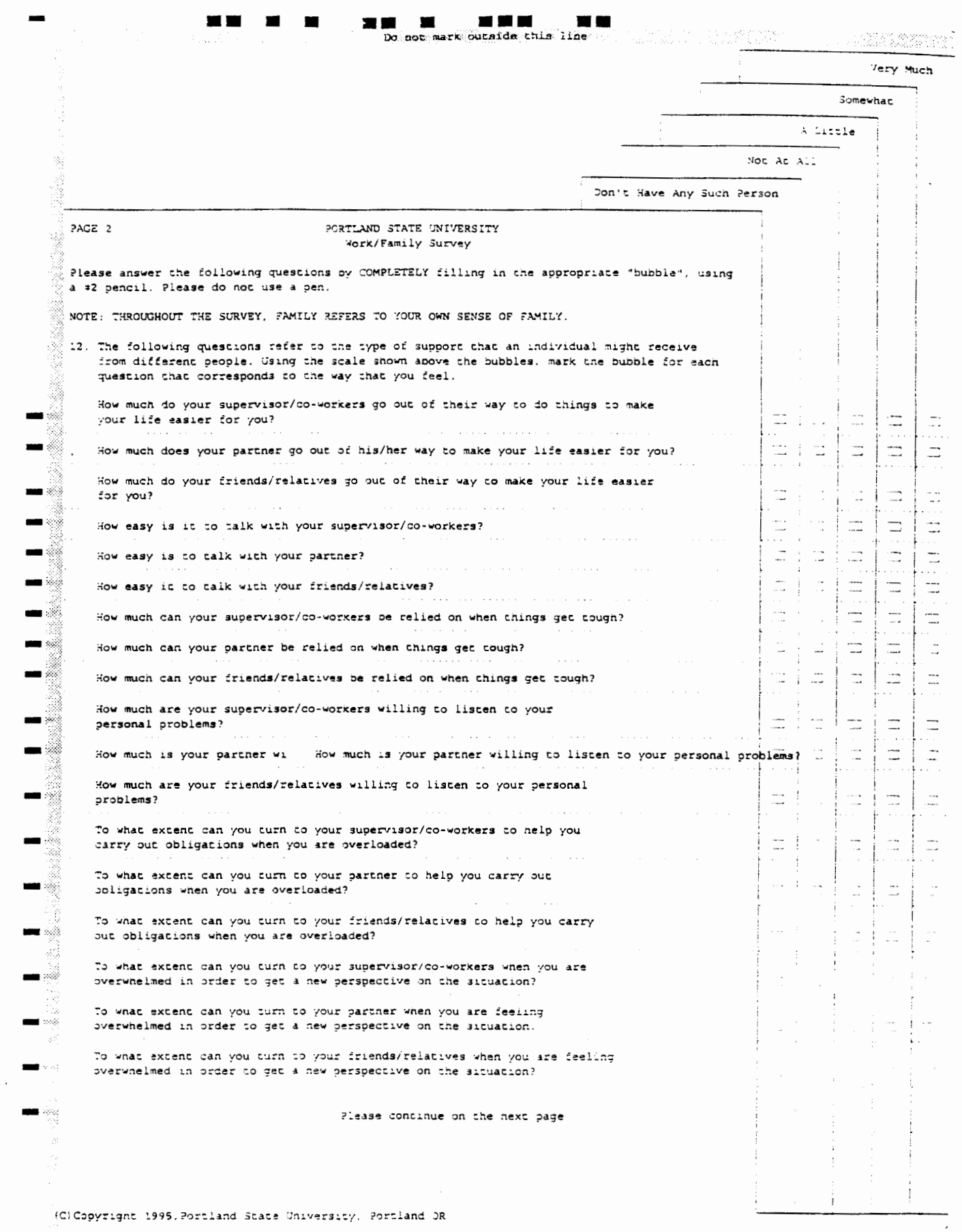




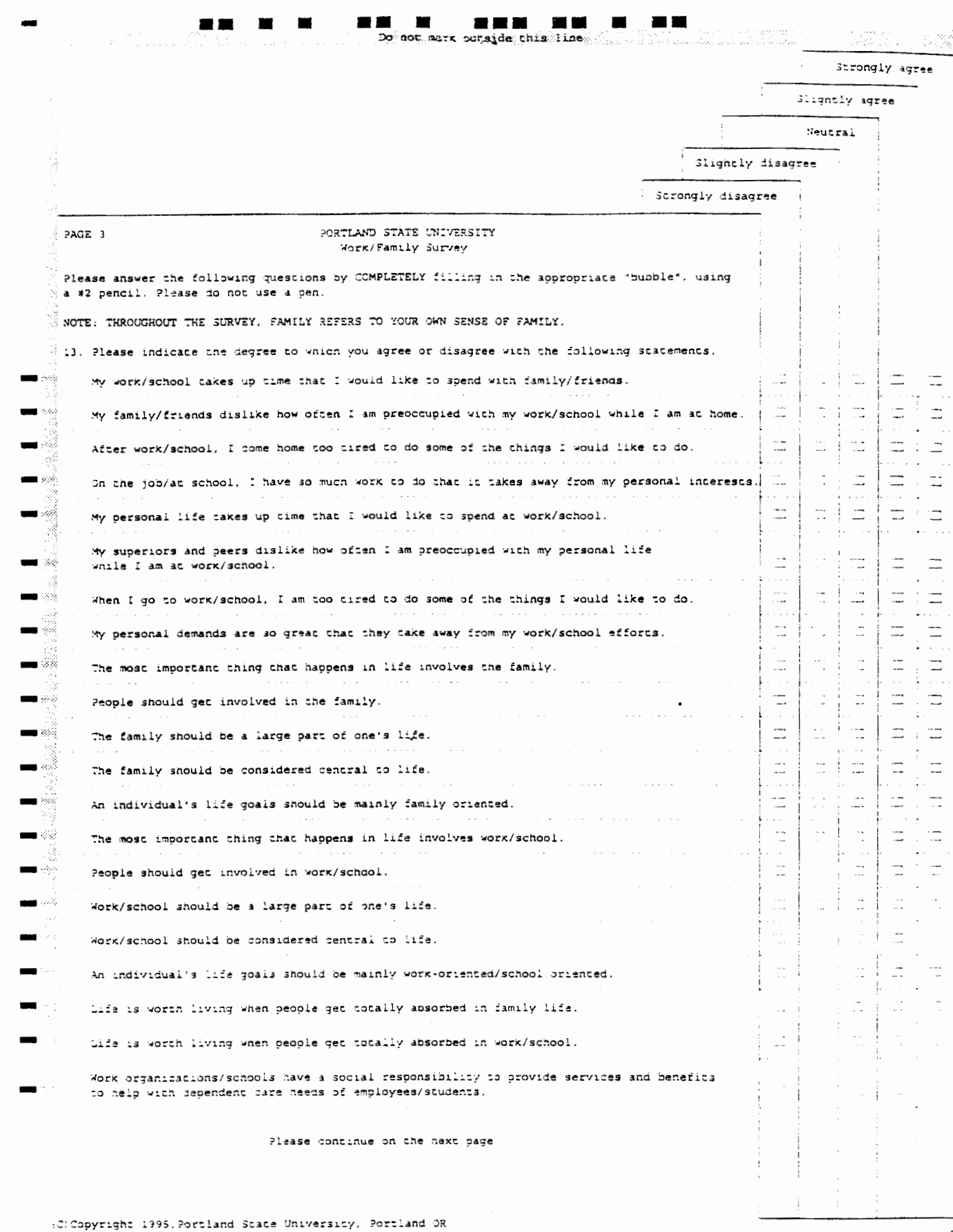


=AGE \&

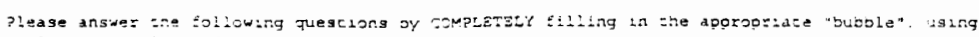

a $\neq 2$ penc: 2 . ?isase do not use a pen.

NOT: THROLCHCC: HHE SURVEY, FAMILY REFERS to YOUR OWN SENSE OE FAMIEY

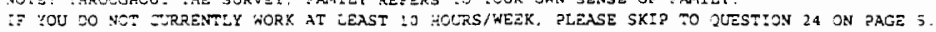

:4. How would You gest clagsiEy your joo?

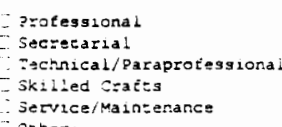

5. How would you best characterize you present work schedule? J standard full-eime

Pare sime

Slexe ime

Compressed work week (e.g.. Gour 10-hour days)

unprediciable variable hourg

. How mues thexibilicy do you have in pous work schedule to handle family ¿amily =eponspibities?
- A lot of Elexibilizy : Some flexibility
- Hardly any Elexibiliey = No Slexibility at $a 11$
:7. How many sours do you work per wesk?
-

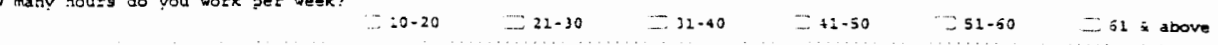

- :8. What is the approximate annual gross income of your hougenold?

Unde= $\$ 25,000 \quad \square 545,000$ and above

23. Thinx apout your yod in general. All in all. what is te like most of the $=1$.ne?

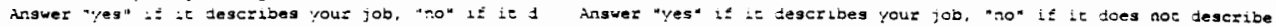
or "?" : $:$ you gan'e tecide.

\begin{tabular}{|c|c|c|c|}
\hline m & Pleasant & ztes & $\ldots$ so \\
\hline & sood & i. res & ... \\
\hline & Accepcasole & Z yes & -... vo \\
\hline & Jisagreeable & $\because$ Yes & ..... No \\
\hline & Excellene & .... Yeg & : No \\
\hline & Enjoyable & … Yes & No \\
\hline & $3 a d$ & $\cdots$ Ves & Y. \\
\hline & Undegi rasle & $\because$ Yes & $\because$ so \\
\hline & Superio: & $\because=s$ & No \\
\hline & Makes ne sontente & tes & No \\
\hline & Rotzen & 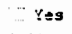 & .. No \\
\hline- & ?200 & ㄱ. Yes & No \\
\hline & Ideal & Yes & :so \\
\hline$=$ & Worehwri:e & $\therefore$ leg & so \\
\hline 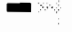 & Jecter =tan mogt & Yes & :a \\
\hline & Haste of $=:$ ine & tes & so \\
\hline - & Horse s:an nost & "es & so \\
\hline & :ardecuacs & $\because=3$ & No \\
\hline
\end{tabular}

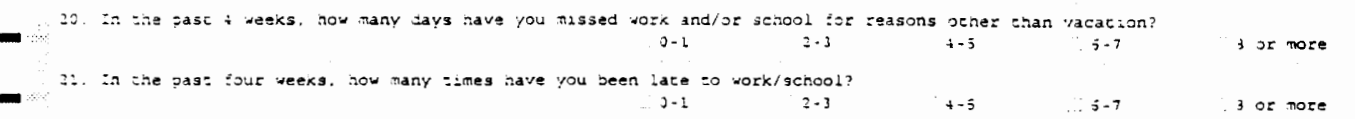

Please continue on the rext gage 


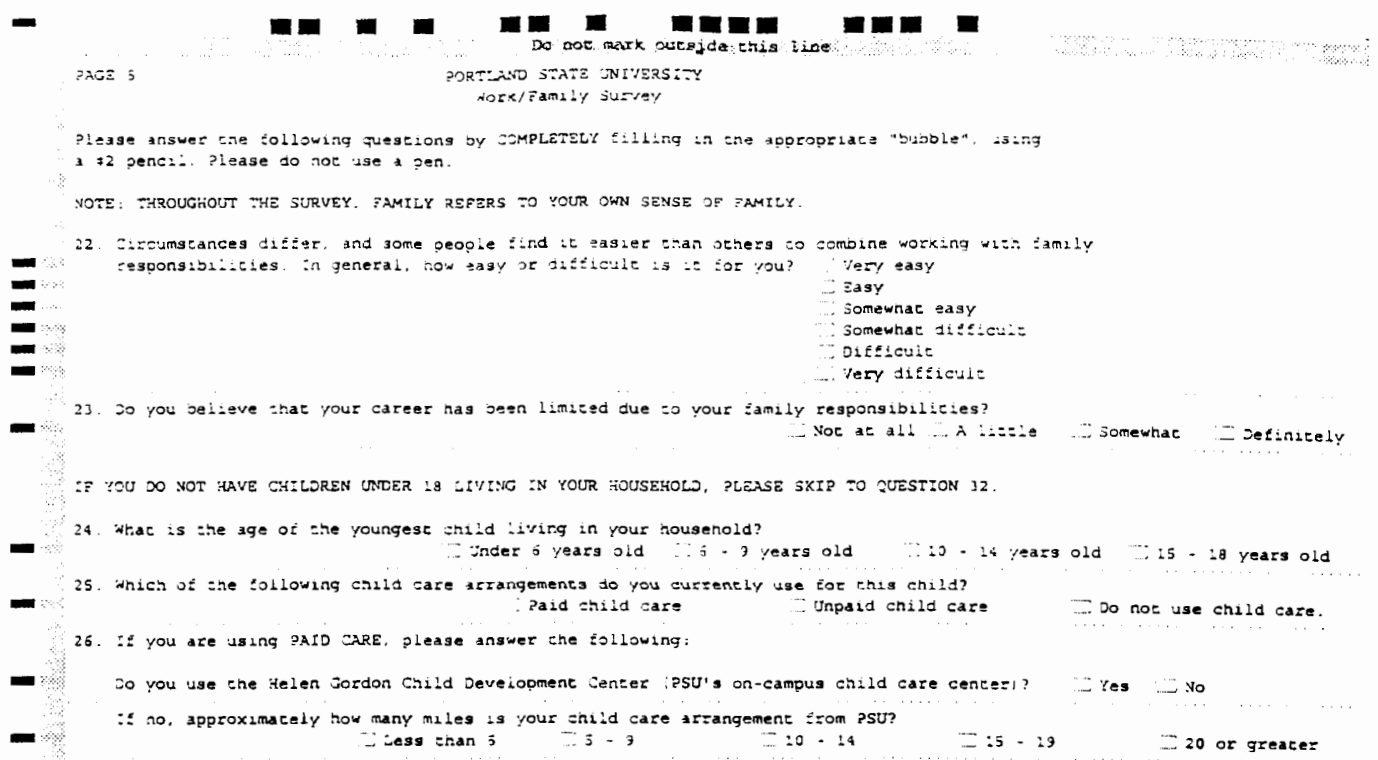

27. Wich regard to your enild care arrangement for your youngest enild, how satisfled are you ditn the pollowing?

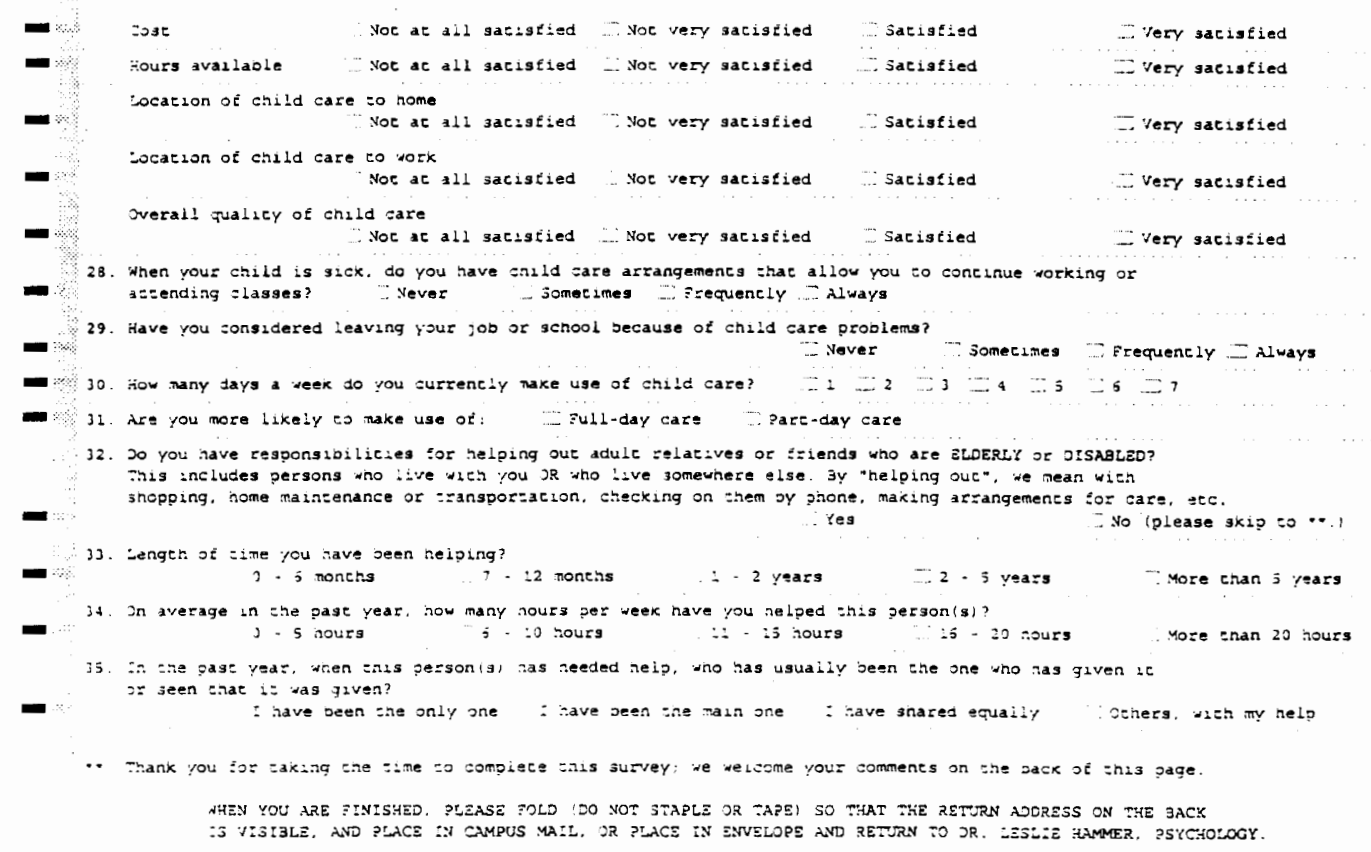

MANK YOU 